\title{
27. VOLCANIC ROCKS OF THE SOUTHEAST GREENLAND MARGIN IN COMPARISON WITH OTHER PARTS OF THE NORTH ATLANTIC TERTIARY IGNEOUS PROVINCE ${ }^{1}$
}

\author{
Lotte Melchior Larsen, ${ }^{2}$ J. Godfrey Fitton, ${ }^{3}$ and Miranda S. Fram ${ }^{4}$
}

\begin{abstract}
The lavas drilled during Ocean Drilling Program Leg 152 on the southeast Greenland Margin cover almost the whole compositional variation found in the North Atlantic volcanic province, ranging from picrites to dacites. Evidence for high-MgO melts, indicating a hotter than normal (plume) mantle is now found in several widespread areas, regardless of the distance to the assumed plume center. In most areas of the North Atlantic, several parallel fractionation trends are present, indicating several independent magma types and magma generation events. Fe- and Ti-enriched fractionated three-phase cotectic basalts are characteristic of the North Atlantic province but are not present at the southeast Greenland Margin except for one young sill. The Tertiary basalts are richer in $\mathrm{FeOT}$ and poorer in $\mathrm{Na}_{2} \mathrm{O}$ than normal mid-ocean-ridge basalts (MORB), indicating melting of hot plume material under a continental/lithospheric lid. The lavas from the southeast Greenland Margin, the Hatton Bank Margin, and the British Isles apparently formed from less hot mantle than the rest. Parts of this southern mantle were more depleted in incompatible elements than the mantle in other areas. The lavas from Hatton Bank and Site 918 have unusually high Sc contents, unparalleled in modern MORBs.

All seaward-dipping reflector sequences drilled up to now (Vøring Margin, Hatton Margin, southeast Greenland Margin) include crustally contaminated rocks in the oldest parts of the sequences. Thick Tertiary dacite successions formed only over the peripheral parts of the mantle plume head. The crustal contaminant at the southeast Greenland Margin is similar to that in the British Isles and Kangerlussuaq and is in strong contrast to the crustal component in the Hatton Bank lavas. This is in accordance with the situation of these areas in different Precambrian structural and age provinces in the North Atlantic region.
\end{abstract}

\section{INTRODUCTION}

The volcanic rocks cored during Leg 152 on the southeast Greenland Margin show a large compositional variation, from dacites that are strongly fractionated and contaminated with continental crust to Mg-rich lavas that appear to have erupted directly from the mantle. The variation is very systematic up-sequence and is thought to reflect magma generation and evolution before, during, and after breakup of the continent (Shipboard Scientific Party, 1994b; Fitton et al., 1995; Chap. 28, this volume). All the drilled rocks are, however, part of the seaward-dipping reflector sequence (SDRS) at the southeast Greenland Margin (except the youngest igneous unit cored, which is a postSDRS sill).

The breakup of the northern Laurasian continent in the early Tertiary was accompanied by eruption of huge amounts of volcanic material onto the continent near the zones of breakup. After breakup, the volcanic activity continued in the form of seafloor spreading in the new North Atlantic ocean basin, a process that has continued to this day on Iceland and along the Mid-Atlantic Ridge. The early Tertiary volcanic rocks are known in a number of areas along the margins of the North Atlantic Ocean (Fig. 1). The compositional variability of the volcanic rocks reflects the variability in the processes responsible for their formation, from generation in the mantle to deposition on the surface. In this paper we examine the compositional variations in the volcanic rocks of the southeast Greenland Margin in comparison to variations reported in other Tertiary volcanic sequences in the North Atlantic.

${ }^{1}$ Saunders, A.D., Larsen, H.C., and Wise, S.W., Jr. (Eds.), 1998. Proc. ODP, Sci. Results, 152: College Station, TX (Ocean Drilling Program).

${ }^{2}$ Geological Survey of Denmark and Greenland, and Danish Lithosphere Centre, Thoravej 8, DK-2400 København K, Denmark. LmL@geus.dk

${ }^{3}$ Department of Geology and Geophysics, Grant Institute, University of Edinburgh, West Mains Road, Edinburgh EH9 3JW, United Kingdom.

${ }^{4}$ Department of Geology, University of California, Davis, CA 95616, U.S.A

\section{THE NORTH ATLANTIC REGION}

The concept of a Tertiary North Atlantic volcanic "province" dates back to Holmes (1918). Brooks (1973) related the magmatism to the continental breakup process and noted that unusual temperatures are indicated. White and McKenzie (1989) suggested that the magmatism in the whole North Atlantic province was due to the Iceland mantle plume, which in the early Tertiary had a diameter of about $2400 \mathrm{~km}$, stretching from Baffin Island in the west to the British Isles in the east. The center of the plume was placed in the Kangerlussuaq area in East Greenland although this is conjectural (e.g., Lawver and Müller, 1994). Presently, the plume is situated beneath Iceland and is decreased in size. The volcanic rocks in all parts of the North Atlantic have some basic geochemical characteristics in common: the majority of the rocks are tholeiitic basalts with low $\mathrm{K}_{2} \mathrm{O}$ and low $\mathrm{SiO}_{2}$, and with isotopic signatures indicating derivation from a depleted mantle source, though not quite as depleted as MORBgenerating mantle. The rocks are very different from the high-SiO ${ }_{2}$, high- $\mathrm{K}_{2} \mathrm{O}$ continental basalts of the Columbia River Plateau and the Paraná and Karoo provinces, but they are broadly similar to some of the basalt units of the Deccan and Ethiopia provinces. They show many similarities to the tholeiitic basalts from Hawaii, testifying that even though many North Atlantic basalts were erupted through and onto continental crust, they commonly escaped contamination with continental material. Contaminated basalts are, however, found in all parts of the province (see "Crustal Contamination" section below).

The following overview takes the volcanic rocks cored during Leg 152 at the southeast Greenland Margin as the starting point. These rocks are then compared with rocks from the continental areas (Kangerlussuaq, Scoresby Sund, Northeast Greenland, West Greenland and Baffin Island, the Faeroe Islands, the Rockall Trough, and the British Isles) and from the two previously drilled continental margins with starting SDRS (the Vøring Plateau and Hatton Bank margins). Comparative data are also included for late Tertiary and Recent 
Figure 1. The North Atlantic region. Areas included in the present overview are indicated by bold lettering. Modified from Larsen, Saunders, Clift, et al., 1994.

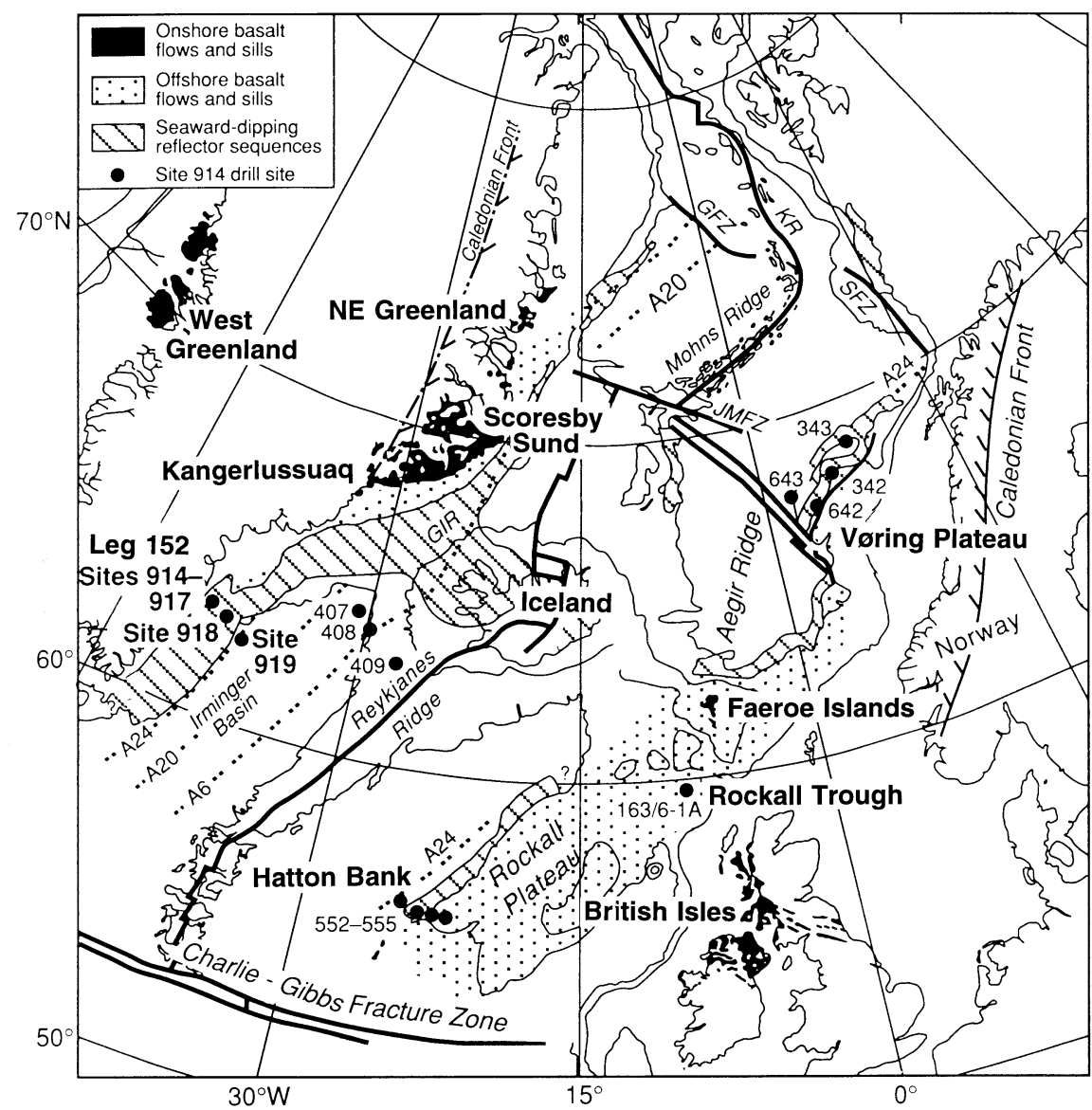

Site 917 Upper Series (917US)

rocks from Iceland, as an expression of the later products from the Iceland mantle plume. The areas are shown in Figure 1, and the data sources are listed in Table 1. Analytical data for Leg 152 are given in the Appendix.

\section{SUMMARY OF THE VOLCANIC SEQUENCE OF LEG 152}

Leg 152 drilled four distinctive volcanic series, as described in Larsen, Saunders, Clift, et al. (1994) and Fitton et al. (1995; this volume). For the purpose of this review they can be summarized as follows, from the oldest to the youngest.

\section{Site 917 Lower Series $(917 L S)$}

This is a pre-breakup series composed of fractionated to primitive basalts. The rocks show signs of fractionation in crustal magma chambers and of contamination with granulite-facies continental crust. Two separate volcanic systems are represented, one with high $\mathrm{Zr} / \mathrm{Nb}(>20)$ and one with low $\mathrm{Zr} / \mathrm{Nb}(<13)$. Lavas of the two systems interfinger in the upper part of the Lower Series.

\section{Site 917 Middle Series (917MS)}

This is a pre-breakup series composed of strongly fractionated siliceous basalts and dacites. All the rocks show signs of strong contamination with siliceous continental crust, and they probably formed under conditions of stagnating magma supply and extended fractionation. The Middle Series is overlain by a fluvial sediment.
This is a syn-breakup series and is composed of MgO-rich basalts and picrites (with $\mathrm{MgO} \geq 15 \%$ ) showing limited or no signs of fractionation in magma chambers, and no crustal contamination. At least two melting events are discernible, the one with the smaller degrees of melting giving rise to more incompatible-element-enriched magmas.

\section{Site 915 and Site 918 SDRS}

These belong to the post-breakup series and are composed of fairly uniform MORB-like basalts. The oldest part of this series is represented by one lava flow from Site 915 and a dike in 917MS. A somewhat younger part is represented by the lavas of Site 918 . The rocks are fractionated basalts filtered through magma chambers in the oceanic crust.

\section{Site 918 Sill}

The youngest volcanic rock drilled is hosted in the sediments overlying the SDRS at Site 918. It is labelled as a sill but it is probably an invasive lava flow from an off-axis central volcano, seen on the nearby seismic profiles.

\section{GENERAL CHARACTER OF VOLCANIC ROCKS IN THE NORTH ATLANTIC}

Figure 2 presents a plot of $\mathrm{TiO}_{2}$ vs. $\mathrm{MgO}$ for the Leg 152 volcanic succession. The primitive, Mg-rich character of the breakup series 
Table 1. Data sources for Figures 2 through 12.

\begin{tabular}{|c|c|}
\hline Location & Data source \\
\hline ODP Leg 152 & $\begin{array}{l}\text { Samples analyzed by XRF in Copenhagen. The results are reported in the Appendix. For the Zr-Sc diagrams the Edinburgh XRF data set was used because the } \\
\text { Edinburgh Sc analyses are } 10 \% \text { lower than the Copenhagen Sc analyses. See Fitton et al. (Chap. } 28 \text {, this volume) and Larsen et al. (Chap. } 35 \text {, this volume). }\end{array}$ \\
\hline Hatton Bank & Morton and Taylor (1987), Merriman et al. (1988), Brodie and Fitton (this volume). \\
\hline Kangerlussuaq & Nielsen et al. (1981), Gill et al. (1988), Holm (1988), Hansen (1993), Fram (1994), and unpubl. data (T.F.D. Nielsen). \\
\hline Scoresby Sund & Larsen et al. (1989) and unpubl. data (L.M. Larsen and W.S. Watt). \\
\hline NE Greenland & Upton et al. (1984), Thirlwall et al. (1994). \\
\hline West Greenland & $\begin{array}{l}\text { Clarke and Pedersen (1976), Hald (1976), Pedersen (1985a, 1985b), Larsen and Pedersen (1990, 1992), Holm et al. (1993), and unpubl. data (L.M. Larsen and } \\
\text { A.K. Pedersen). }\end{array}$ \\
\hline Baffin Island & Clarke (1968), Francis (1985), Robillard et al. (1992). \\
\hline Vøring Plateau & Viereck et al. (1988, 1989), Parson et al. (1989), Taylor and Morton (1989). \\
\hline Faeroe Islands & Gariépy et al. (1983), Hald and Waagstein (1984), Waagstein and Hald (1984), Waagstein (1988). \\
\hline Rockall Trough & Morton et al. (1988). \\
\hline British Isles & $\begin{array}{l}\text { Thompson et al. (1972, 1980, 1982, 1986), Beckinsale et al. (1978), Moorbath and Thompson (1980), Dickin (1981), Emeleus (1985), Dickin et al. (1987), } \\
\text { Wallace et al. (1994), Scarrow and Cox (1995). }\end{array}$ \\
\hline Iceland & Tertiary: Unpubl. data from Northwest Iceland (J.G. Fitton and B. Hardarson). Recent: Hémond et al. (1993). \\
\hline Basement gneiss & This is represented by sample GGU 324721, an Archaean gneiss from the nearby Greenland coast, from Blichert-Toft et al. (1995). \\
\hline
\end{tabular}

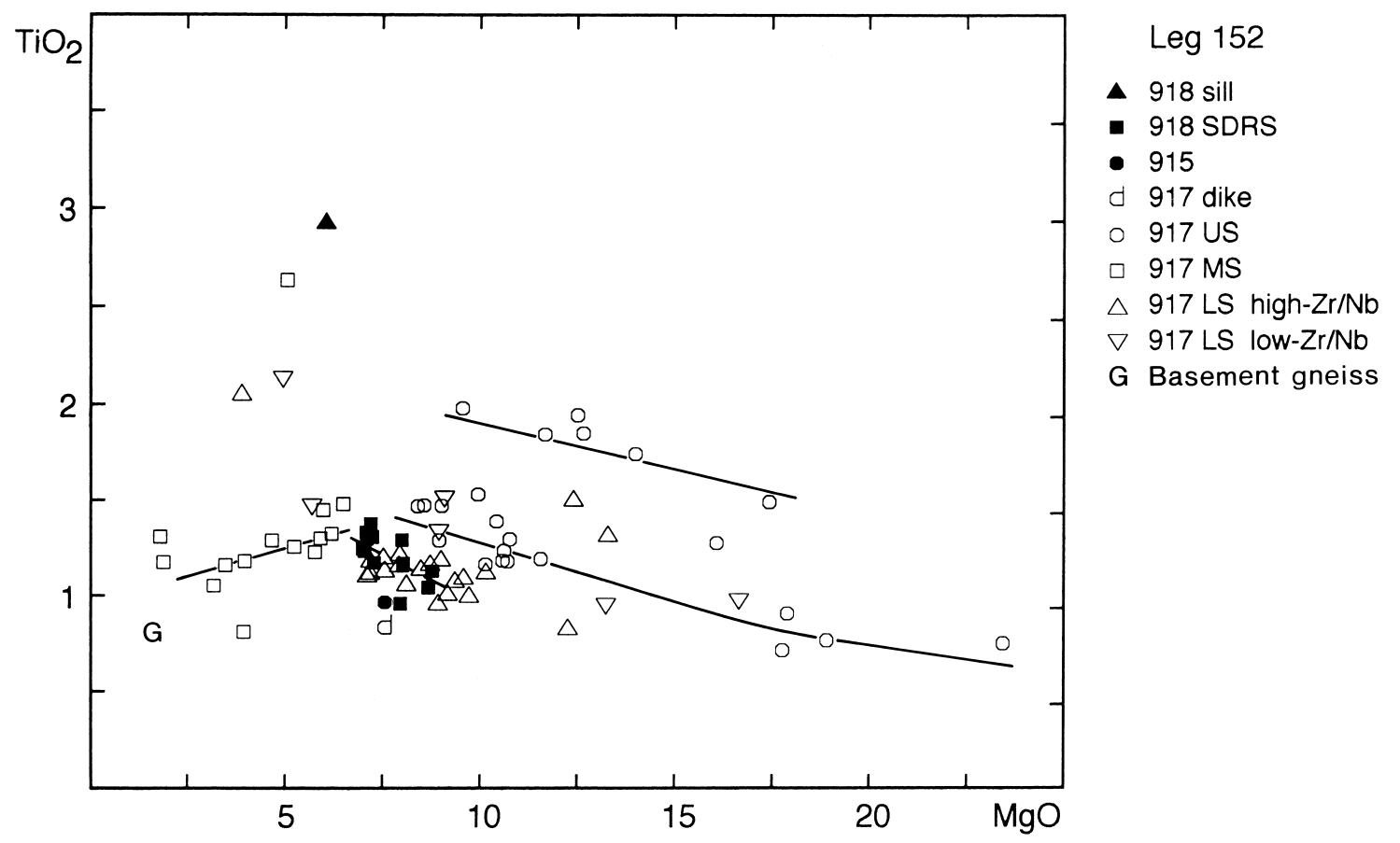

Figure 2. $\mathrm{TiO}_{2}$ vs. $\mathrm{MgO}$ for the Leg 152 volcanic succession.

(917US) is clearly seen. Two parallel olivine fractionation trends in 917US are evident, the more Ti-rich trend probably representing a separate melting episode with smaller degrees of melting (Shipboard Scientific Party, 1994a; Fram et al., this volume). The rocks of 917LS show a large scatter but are generally very poor in $\mathrm{TiO}_{2}$. Most of the siliceous rocks of $917 \mathrm{MS}$ are also very poor in $\mathrm{TiO}_{2}$, partly due to oxide fractionation. The most $\mathrm{TiO}_{2}$-rich rock is the young sill at Site 918.

Figure 3 presents a comparative plot for the North Atlantic, with the various regions simplified into trends in order to maintain clarity. A number of parallel fractionation trends are evident. The shallow part of the trends represent olivine fractionation or, at the higher $\mathrm{MgO}$ values, olivine accumulation; at around $10 \%-8 \% \mathrm{MgO}$ fractionating olivine is joined by plagioclase, and shortly afterward by clinopyroxene. The three-phase cotectic basalts normally show a sharp inflection of the fractionation trend, which turns steeply up toward enrichment in $\mathrm{TiO}_{2}$ (and $\mathrm{FeO}$, not shown). In the $\mathrm{TiO}_{2}$-rich trend from Kangerlussuaq, clinopyroxene appears before plagioclase (Nielsen et al., 1981).

The $\mathrm{TiO}_{2}-\mathrm{MgO}$ diagram shows the following main features.
1. $\mathrm{MgO}$-rich, primitive (picritic) rocks with $\mathrm{MgO} \geq 15 \%$ were produced in notable quantities in several widely spaced areas in the North Atlantic. How many of these rocks are cumulates and how many represent melt compositions is conjectural. The formation of dry picritic melts requires that the mantle temperature was hotter than normal (McKenzie and Bickle, 1988), and therefore conclusions about the existence of such melts have important consequences for inferences about mantle temperatures. Highly magnesian melts will be in equilibrium with highly magnesian olivine (Roeder and Emslie, 1970), and, even though a high-Mg rock may contain accumulated olivine, the presence of highly magnesian olivine phenocrysts, however sparse, will indicate that a high-MgO melt did exist. Such highly magnesian olivine phenocrysts, all in calculated equilibrium with melts with more than $15 \% \mathrm{MgO}$, have been found in West Greenland $\left(\mathrm{Fo}_{90-92.5}\right.$; Pedersen, 1985b), Kangerlussuaq $\left(\mathrm{Fo}_{88-90}\right.$; Nielsen et al., 1981; Hansen, 1993; Fram and Lesher, in press), and in Site 917US ( $\mathrm{Fo}_{92.5}$; Demant, this volume). A few rocks from the Rockall Trough and the British Isles contain just around $15 \% \mathrm{MgO}$, and rare liquids with around $18 \% \mathrm{MgO}$ are inferred based on olivine compositions (McClurg, 1982; Bell and Williamson, 1994; Kent, 1995). The Re- 


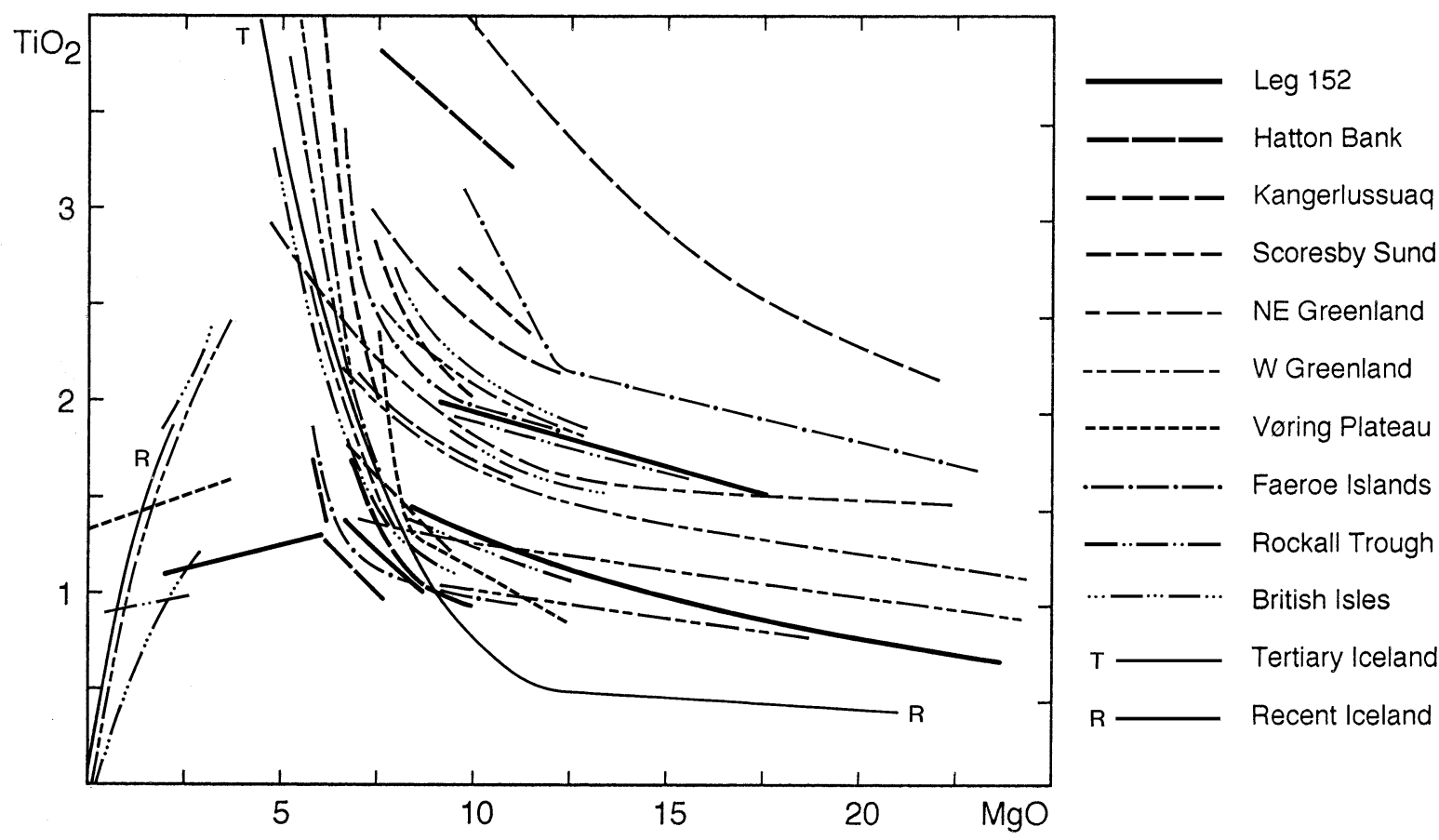

Figure 3. $\mathrm{TiO}_{2}$ vs. $\mathrm{MgO}$ for the North Atlantic region. The large amount of data are simplified into trend lines. The Baffin Island trend coincides with the West Greenland low- $\mathrm{TiO}_{2}$ trend. For data sources, see Table 1. See text for discussion.

cent Iceland data set includes picrites, some of which may represent liquids (Elliott et al., 1991), others cumulates (Hansteen, 1991). The status of the picrites in the Faeroe Islands is uncertain.

The MgO-rich ends of some of the trends are thought to be caused by olivine accumulation; this is the case for the MgO-rich rocks in Northeast Greenland (Thirlwall et al., 1994). The West Greenland trend goes up to $30 \% \mathrm{MgO}$ but no liquids with more than $19 \% \mathrm{MgO}$ are indicated (Pedersen, 1985b; Gill et al., 1992).

It is not possible to conclude whether MgO-rich, hot magmas were produced in other regions such as Scoresby Sund and the Vøring Plateau. The record from Leg 152 clearly shows that such magmas only gain access to the surface under special conditions that may prevail during short time intervals only. Still, the occurrence of Paleocene-Eocene picrites in widely spaced regions and at the periphery of the reconstructed mantle plume causes problems for the models of temperature distribution within the plume head that assume higher temperatures at the center and lower at the periphery. This is discussed in length by Larsen et al. (1992), Gill et al. (1992), Kent (1995), and Chalmers et al. (1995), among others.

2. A number of individual fractionation trends are present at different levels of $\mathrm{TiO}_{2}$-content. This indicates that a range of parental liquid compositions, with different $\mathrm{TiO}_{2}$ contents, was involved. Individual areas usually possess more than one trend and hence more than one parental liquid composition, and each trend often, but not always, represents a distinct stratigraphic unit. The Faeroe Islands are extreme in this respect, with rocks ranging from very "enriched" in the Middle Series to a mixture of very enriched and very "depleted" in the Upper Series (Waagstein, 1988). Explanations for the different trends within an area range from different degrees of melting of the same mantle (Leg 152 917US: Shipboard Scientific Party, 1994a; North Atlantic as a whole: Fram and Lesher, 1993) to contamination of asthenospheric melt by lithospheric mantle or crust (Kangerlussuaq: Gill et al., 1988; Holm, 1988; Leg 152 917LS: Shipboard Scientific Party, 1994a), to heterogeneous mantle plume material (Iceland: Hémond et al., 1993). More than one explanation may apply to an area, as is the case for Leg 152.
3. The steep trend toward strong enrichment in $\mathrm{TiO}_{2}$ (and iron, not shown) when the liquids fractionate olivine + plagioclase + clinopyroxene is not seen in Leg 152 and is only poorly developed in Hatton Bank. Most North Atlantic areas show a large data concentration around $6 \%-8 \% \mathrm{MgO}$ and $1.5 \%-3 \% \mathrm{TiO}_{2}$ (Fig. 3), but this field is notably empty in the Leg 152 diagram (Fig. 2). Fe- and Ti-rich basalts are a hallmark of continental and ocean island basalts, and especially the basalts of the North Atlantic. The 917LS, 917MS, and 918 SDRS rocks are sufficiently fractionated for this Fe-Ti-enrichment to show up, but it does not. The 917LS and 917MS may perhaps be Fe-Ti-depleted by crustal contamination and early Fe-Ti oxide precipitation (see "Crustal Contamination" section below). The 918 SDRS lavas are very similar to the least fractionated lavas from the Hatton Bank. The lack of Fe-Ti-rich rocks at the southeast Greenland and Hatton Bank margins places these in strong contrast to all the other parts of the North Atlantic region, and makes them more akin to oceanic areas producing N-MORB. Of the Leg 152 samples only four, all with $\mathrm{MgO}<7 \%$, show the "normal" Ti- and Fe-enrichment. One of these is the late sill in Hole 918 (Fig. 2).

4. The 917US comprises an olivine fractionation trend with a level of $\mathrm{TiO}_{2}$ content that is by no means low in relation to the other olivine fractionation trends in the North Atlantic.

5. Crustally contaminated rocks trend toward low $\mathrm{MgO}$ at low constant or decreasing $\mathrm{TiO}_{2}$, probably because of both assimilation and oxide fractionation (see "Crustal Contamination" section below). Many of these highly fractionated rocks are dacitic and rhyolitic, not basaltic.

\section{CRUSTAL CONTAMINATION}

Crustal contamination is demonstrated in Figures 4 and 5, $\mathrm{TiO}_{2}$ vs. $\mathrm{SiO}_{2}$. Normal basalt fractionation trends in this diagram extend toward $\mathrm{TiO}_{2}$-enrichment at near-constant $\mathrm{SiO}_{2}$ levels. Assimilation of siliceous crustal rocks leads to $\mathrm{SiO}_{2}$-enrichment at constant or decreasing $\mathrm{TiO}_{2}$ because of $\mathrm{Fe}-\mathrm{Ti}$ oxide fractionation. A similar $\mathrm{SiO}_{2}$ - 


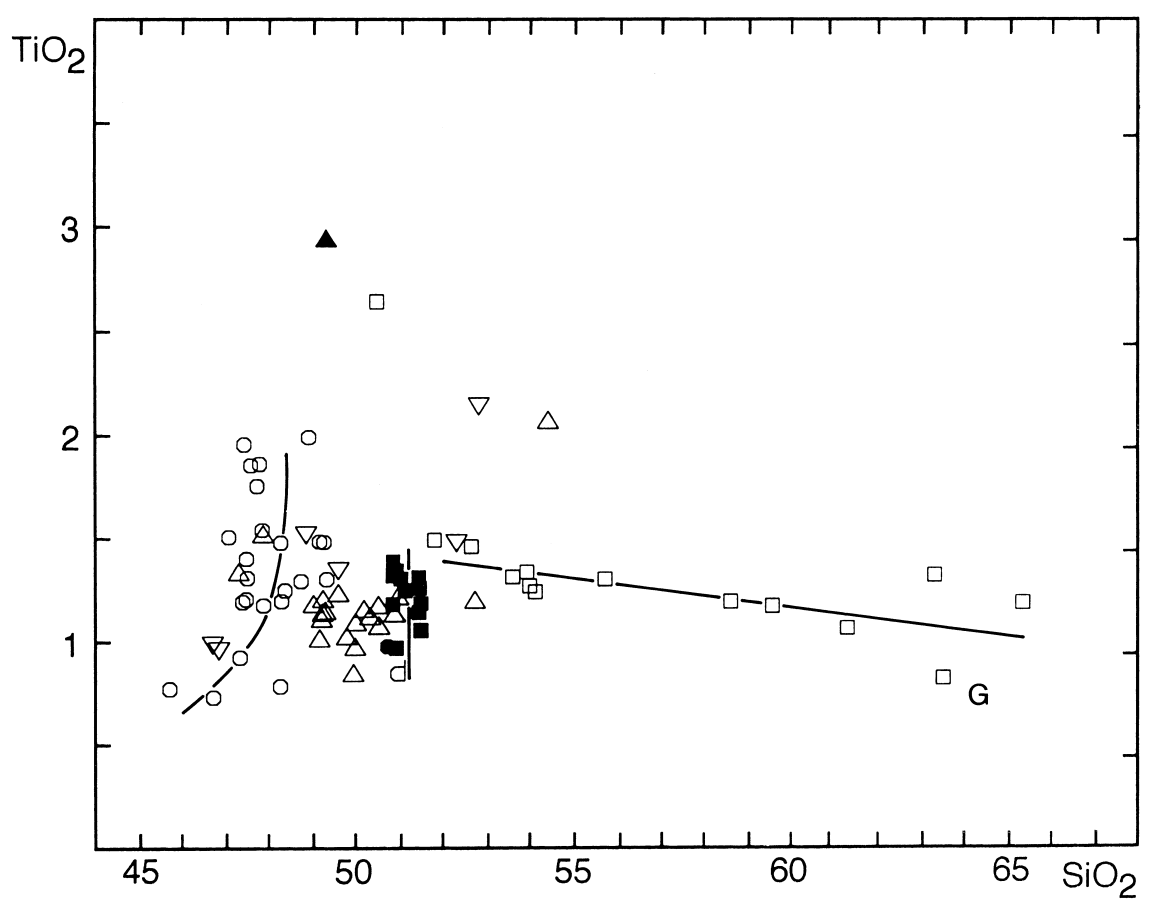

Leg 152

- 918 sill

- 918 SDRS

- 915

d 917 dike

- 917 US

口 $917 \mathrm{MS}$

$\triangle 917$ LS high-Zr/Nb

$\nabla 917$ LS low-Zr/Nb

$G$ Basement gneiss

Figure 4. $\mathrm{TiO}_{2}$ vs. $\mathrm{SiO}_{2}$ for the Leg 152 volcanic succession.

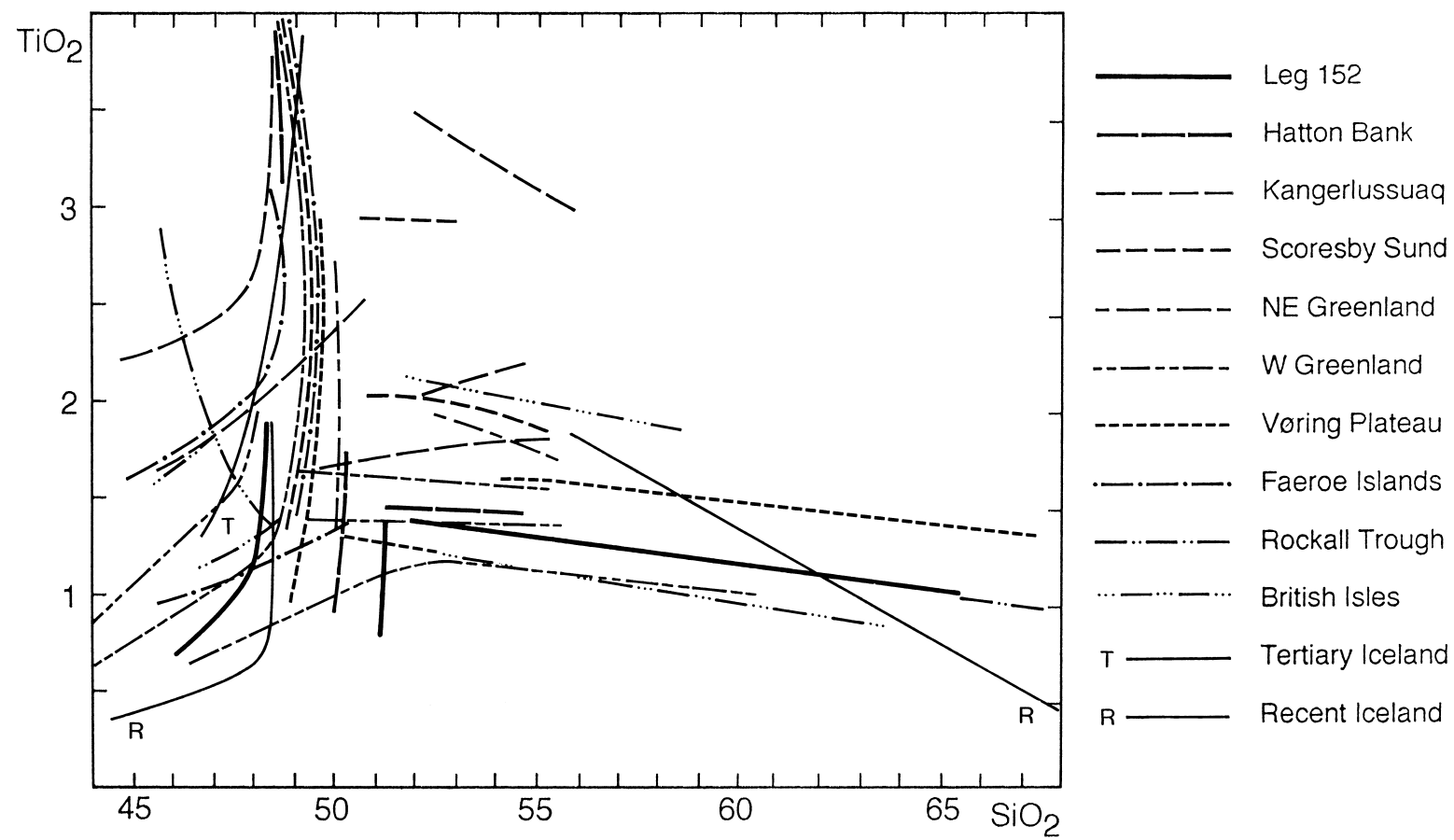

Figure 5. $\mathrm{TiO}_{2}$ vs. $\mathrm{SiO}_{2}$ for the North Atlantic region. The large amount of data is simplified into trend lines. See text for discussion.

enrichment trend may also be produced by prolonged fractionation including oxide minerals, without any crustal contamination, and isotope data are ultimately desirable to decide what causes a $\mathrm{SiO}_{2}$ enrichment trend.

As shown in Figure 5, the majority of uncontaminated basalts in the North Atlantic have $\mathrm{SiO}_{2}$ contents of $48 \%-50 \%$. Most continental basalts from the North Atlantic with $\mathrm{SiO}_{2}>51 \%$ show indications of crustal contamination (high $\mathrm{K}, \mathrm{Rb}$, and $\mathrm{Ba}$ contents; disturbed radio- genic isotope ratios). In contrast, basalts produced in an oceanic environment may have $\mathrm{SiO}_{2}>51 \%$ as an effect of melting at lower pressures than beneath a continental lid (e.g., McKenzie and Bickle, 1988).

Figure 4 shows $\mathrm{TiO}_{2}$ vs. $\mathrm{SiO}_{2}$ for the southeast Greenland Margin. The 917US and a few rocks from the 917LS (mostly from the low$\mathrm{Zr} / \mathrm{Nb}$ group) follow a normal basalt fractionation trend. Relative to this, most rocks from $917 \mathrm{LS}$ have increased $\mathrm{SiO}_{2}$ by $1 \%-2 \%$. Almost 
all rocks from $917 \mathrm{MS}$ are strongly Si-enriched at constant $\mathrm{TiO}_{2}$. When considering the whole geochemical spectrum of these rocks (Appendix), some element correlations (such as positive correlation between $\mathrm{SiO}_{2}$ and $\mathrm{Ce} / \mathrm{Y}$ ) cannot be explained by crystal fractionation alone. In almost all plots the 917MS rocks lie on a trend extending from normal basalts toward a sample of the local Archaean basement gneiss (Figs. 2, 4, 6, 9), and the trend is best explained as resulting from combined crustal assimilation and fractional crystallization (Fitton et al., Chaps. 28 and 29, this volume).

The 917LS has assimilated material with high $\mathrm{Ba} / \mathrm{Zr}$ (see below) and high Sr/Zr, and Fitton et al. (Chap. 29, this volume) suggest that this material is lower crustal granulite. The 1\%-2\% increase in $\mathrm{SiO}_{2}$ shown by most rocks in the 917LS may be due to such assimilation.

The 918 SDRS rocks have relatively high $\mathrm{SiO}_{2}(50.5 \%-51.5 \%)$, although they have not been erupted through continental but oceanic crust; this suggests melting at low pressure under a thin (oceanic) lid as discussed above.

Data for the North Atlantic are shown in Figure 5. Extensive silica enrichment in voluminous rocks is seen in southeast Greenland, the Vøring Plateau, the Rockall Trough, the British Isles, and West Greenland (excluding Baffin Island). In southeast Greenland and the Vøring Plateau these rocks occur in the oldest part of the dipping reflector sequence on the continental margin. Parts of the SDRS at the Hatton Bank Margin are also contaminated (Site 553) but are less fractionated. In contrast, the thick volcanic sequences in the Faeroe Islands and East Greenland (Kangerlussuaq, Scoresby Sund, and Northeast Greenland) show much less extensive contamination, and the contaminated basalts are not highly fractionated. Indeed, the data suggest that for the early Tertiary, dacites and rhyolites are characteristic of the more peripheral areas over the mantle plume head, and are rare or absent over the more central areas. The production of acid magmas will reflect both tectonic conditions (possibilities of trapping of melts in crustal magma chambers) and magma production rates (residence times in the magma chambers).

Contamination with lower crust and lithospheric mantle like that invoked for 917LS has also been advocated for some of the Lower basalts from the Kangerlussuaq area (Holm, 1988; Gill et al., 1988).
In Iceland the Si-enriched rocks form central complexes and are considered to be formed by melting of hydrated basaltic crust (Óskarsson et al., 1985; Hémond et al., 1993).

Figures 6 and 7 show $\mathrm{Ba} / \mathrm{Zr}$ vs. $\mathrm{SiO}_{2}$. Uncontaminated tholeiitic basalts have $\mathrm{Ba} / \mathrm{Zr}$ below $1-2$, and accordingly the apparently uncontaminated rocks in Leg 152 (917US, dike, 915, 918 SDRS and sill, and a few 917LS samples) have low $\mathrm{Ba} / \mathrm{Zr}$ (Fig. 6). Contamination with crustal rocks often leads to increased $\mathrm{Ba} / \mathrm{Zr}$. Most of the $917 \mathrm{LS}$ and $917 \mathrm{MS}$ have $\mathrm{Ba} / \mathrm{Zr}$ between 2 and 5, with a weak positive correlation between $\mathrm{Ba} / \mathrm{Zr}$ and $\mathrm{SiO}_{2}$ in $917 \mathrm{MS}$. A few samples have even higher $\mathrm{Ba} / \mathrm{Zr}$ (outside the diagram). $\mathrm{Ba} / \mathrm{Zr}$ values greater than 3 are not common in the North Atlantic (Fig. 7). Increased $\mathrm{Ba} / \mathrm{Zr}$, often positively correlated with $\mathrm{SiO}_{2}$, is seen in most of the contaminated rocks, but even the strongly contaminated rocks from West Greenland, the Rockall Trough, and the $\mathrm{V} \varnothing$ ring Plateau have $\mathrm{Ba} / \mathrm{Zr}<3$. The contaminated rocks from the Hatton Bank have very low $\mathrm{Ba} / \mathrm{Zr}(<1)$. However, many rocks from the British Isles and some from Kangerlussuaq have $\mathrm{Ba} / \mathrm{Zr}$ values corresponding to those of the southeast Greenland Margin. The British rocks also show a corresponding weak positive correlation with $\mathrm{SiO}_{2}$.

The following main points can be made.

1. All SDRS drilled up to now (Vøring Margin, Hatton Margin, southeast Greenland Margin) include crustally contaminated rocks in the oldest parts of the sequences.

2. All lava successions on the continent include crustally contaminated rocks. Some successions are only sporadically contaminated, whereas others show extensive contamination leading to dacite formation. Thick Tertiary dacite successions formed only over the peripheral parts of the mantle plume head.

3. The crustal contaminant at the southeast Greenland Margin has trace element characteristics (high $\mathrm{Ba} / \mathrm{Zr}$ ) similar to that in the British Isles and to some extent Kangerlussuaq. It is in strong contrast to the crustal component in the Hatton Bank lavas, indicating major differences in basement compositions. Site 917, Kangerlussuaq, and the British Isles north of the Great Glen Fault are all situated within Archaean basement, whereas the Hatton Bank Margin, on a plate reconstruction, is situated $\sim 400 \mathrm{~km}$ south of Sites $915-918$ and lies in the

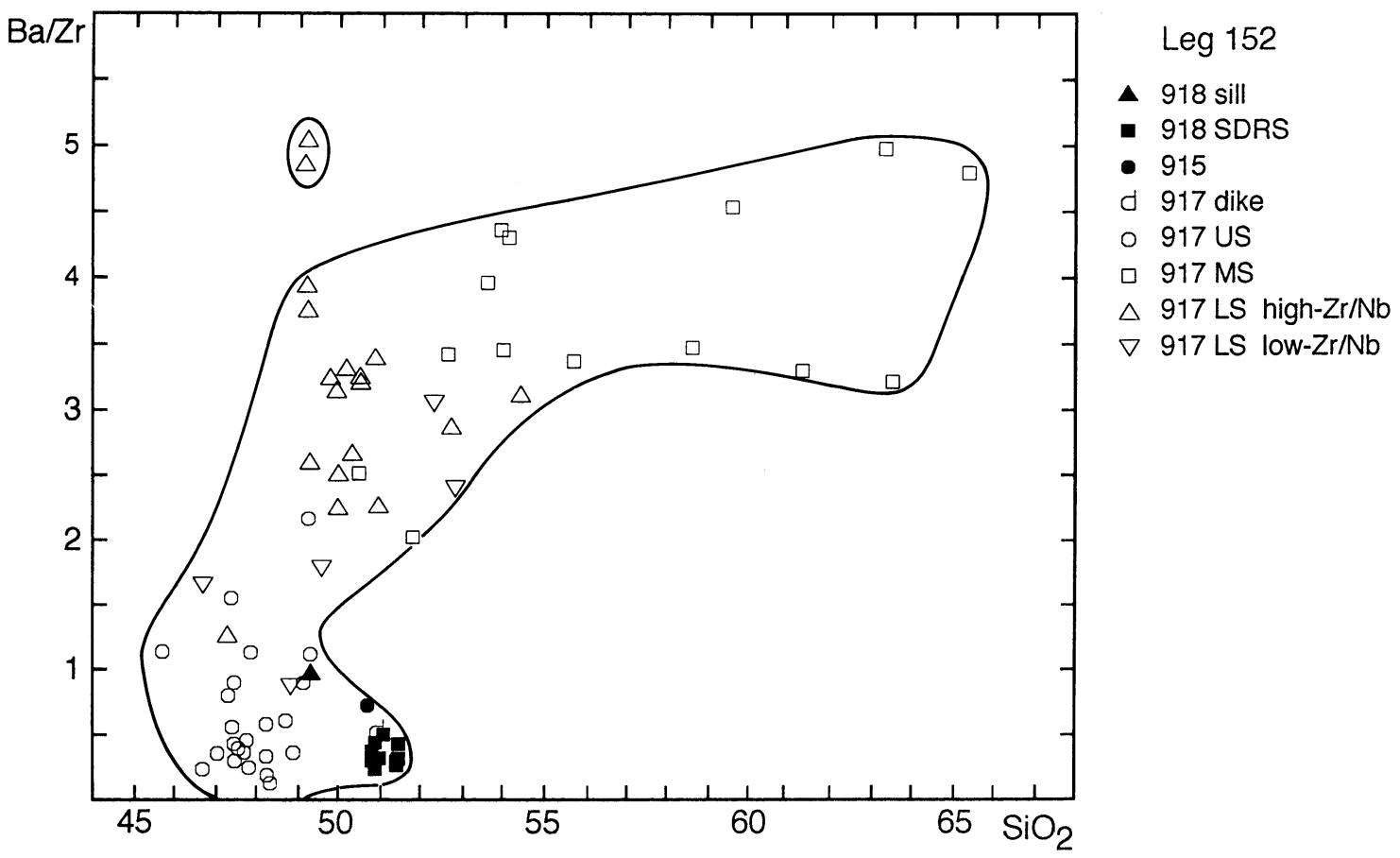

Figure 6. $\mathrm{Ba} / \mathrm{Zr}$ vs. $\mathrm{SiO}_{2}$ for the Leg 152 volcanic succession. Four data points for $917 \mathrm{LS}$ plot outside the limits of the diagram, with $\mathrm{Ba} / \mathrm{Zr}=10-16 . \mathrm{The}$ basement gneiss sample has $\mathrm{Ba} / \mathrm{Zr}=7.0$ at $\mathrm{SiO}_{2}=64.25$. 


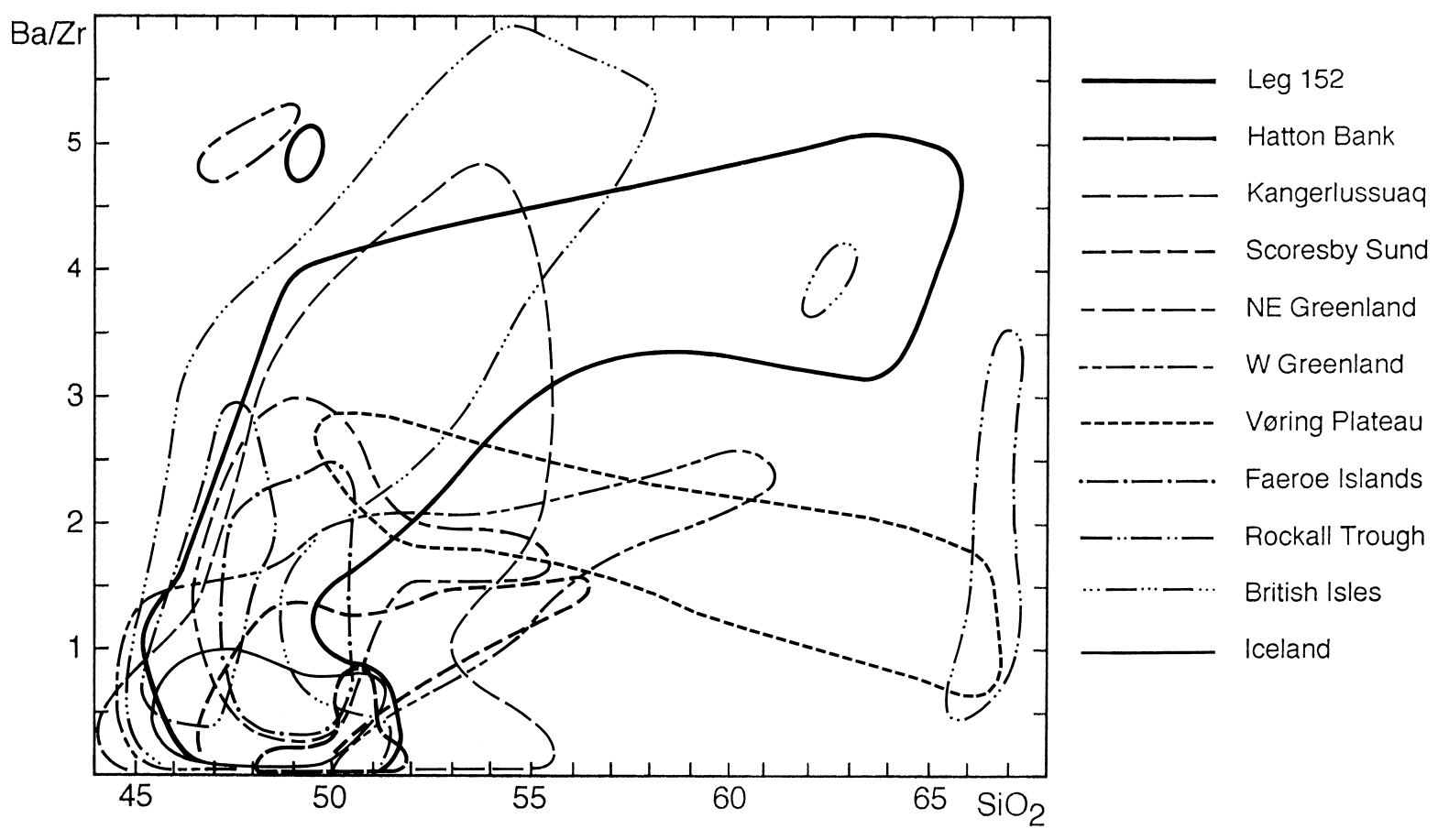

Figure 7. $\mathrm{Ba} / \mathrm{Zr}$ vs. $\mathrm{SiO}_{2}$ for the North Atlantic region. Data fields for the different areas are encircled. See text for discussion.

projected eastern extension of the mainly juvenile early Proterozoic (1700-1900 Ma) Ketilidian Mobile Belt in South Greenland (e.g., Dickin, 1992). On reconstructions such as that in Harris (1991, fig. 1.2), with the suggested position of the Late Proterozoic Grenville Front, the Hatton Bank area even falls within the Grenvillean orogenic belt. In any case, the basement in the Hatton Bank area is significantly younger than in the Leg 152 area, Kangerlussuaq, and the northwestern British Isles.

\section{MANTLE CHARACTER AND MELTING PROCESSES}

Fram and Lesher (1993) compiled data for the North Atlantic and used variations in $\mathrm{TiO}_{2}$, FeOT (total iron as $\mathrm{FeO}$ ), and $\mathrm{Dy} / \mathrm{Yb}$ to demonstrate a trend toward higher degrees of melting in the mantle at lower mean pressures with time, attributed to progressive thinning of the lithospheric lid. Here, we examine the variations in $\mathrm{Na}_{2} \mathrm{O}, \mathrm{FeOT}$, $\mathrm{Ce} / \mathrm{Y}$, and $\mathrm{Zr} / \mathrm{Nb}$.

The diagram $\mathrm{Na}_{2} \mathrm{O}$ vs. FeOT was used by Klein and Langmuir (1987) and Langmuir et al. (1992) in conjunction with a melting model for oceanic basalts. Analyses of MORB glasses were plotted after correction for fractionation to $8 \% \mathrm{MgO}$. For the continental basalts discussed here, this diagram is difficult to use unmodified for two reasons. The first is that $\mathrm{Na}_{2} \mathrm{O}$ is often affected by secondary alteration, which produces a scatter in $\mathrm{Na}_{2} \mathrm{O}$ toward both lower and higher values than the original. Therefore, the data have to be filtered. For this purpose, rocks with more than $4.5 \%$ volatiles were excluded; also some other rocks with obviously disturbed $\mathrm{Na}_{2} \mathrm{O}$ (as seen in a $\mathrm{Na}_{2} \mathrm{O}$ vs. $\mathrm{MgO}$ plot) were excluded. Still, the data from Kangerlussuaq, the Vøring Plateau, and the Rockall Trough did not form consistent clusters and were discarded. Data from the other areas plot in consistent clusters that do not change when only the freshest rocks are plotted. Thus, if the various groups seen in Figure 8 are spurious and due to alteration, all the samples within one area (e.g., the southeast Greenland Margin with its relatively high $\mathrm{Na}_{2} \mathrm{O}$ ) are equally affected and are displaced in the same direction. This is unlikely. Alteration by seawater may perhaps be called on to explain the high $\mathrm{Na}_{2} \mathrm{O}$ at the southeast Greenland Margin; on the other hand, the volcanic rocks in
West Greenland, which were deposited partly in a marine basin (Larsen et al., 1992), show no differences between marine and nonmarine deposits. The most likely explanation for the different clusters seen in Figure 8 is primary differences in $\mathrm{Na}_{2} \mathrm{O}$ contents.

The second difficulty with the $\mathrm{Na}_{2} \mathrm{O}-\mathrm{FeOT}$ diagram is the use of fractionation correction to $8 \% \mathrm{MgO}$ for oceanic basalts. As noted earlier, most North Atlantic basalts with less than $7 \%-8 \% \mathrm{MgO}$ trend very steeply toward enrichment in $\mathrm{Fe}$ and $\mathrm{Ti}$ (Fig. 3). This makes extrapolation back to $8 \% \mathrm{MgO}$ very uncertain, and lavas with $<7 \%-8 \%$ $\mathrm{MgO}$ are generally of little use in ascertaining the level of FeOT in the more primitive liquid precursors.

After inspection of variation diagrams of $\mathrm{Na}_{2} \mathrm{O}$ and $\mathrm{FeOT}$ vs. $\mathrm{MgO}$ (not shown here), it was decided only to use basalt analyses with $8 \%-12 \% \mathrm{MgO}$. In this interval many rock suites have near-constant FeOT values because they evolve by fractionation of olivine with an iron content close to that of the magma, and fractionation corrections to $8 \% \mathrm{MgO}$ on $\mathrm{FeOT}$ are very small. The interval $8 \%-12 \%$ $\mathrm{MgO}$ corresponds to $8 \%-9 \%$ olivine fractionation, and a $\mathrm{Na}_{2} \mathrm{O}$ correction factor of 1.1 could be applied to the lavas with close to $12 \%$ $\mathrm{MgO}$. This will produce a slight upward shift of the low- $\mathrm{Na}_{2} \mathrm{O}$ ends of the data fields in Figure 8, but the upper ends are unchanged. In some cases no changes at all are produced by the correction. Consequently, to treat all the data equally, no fractionation corrections were applied to the $\mathrm{Na}_{2} \mathrm{O}-\mathrm{FeOT}$ diagram shown here in Figure 8. The results are unchanged by using a narrower $\mathrm{MgO}$ interval (e.g., $8 \%-$ $10 \% \mathrm{MgO}$ ) but fewer rocks define the fields. The use of a $\mathrm{MgO}$ interval without any fractionation correction makes the diagram in principle slightly different from the Klein and Langmuir diagram.

Langmuir et al. (1992) calculated a liquid composition produced by "standard" melting (10\%) of standard oceanic mantle and pooling of the melts through the melting column; at $8 \% \mathrm{MgO}$ this liquid has $8.5 \% \mathrm{FeOT}$ and $2.4 \% \mathrm{Na}_{2} \mathrm{O}$. The majority of the North Atlantic rocks shown in Figure 8 were not produced in an oceanic setting but beneath a continental lid, which truncated the melting column. Other things being equal this will lead to production of melts richer in iron than normal oceanic melts because the low-pressure melt fractions are missing. The high FeOT values in the North Atlantic basalts relative to normal MORB are likely an effect of the continental lid, as 


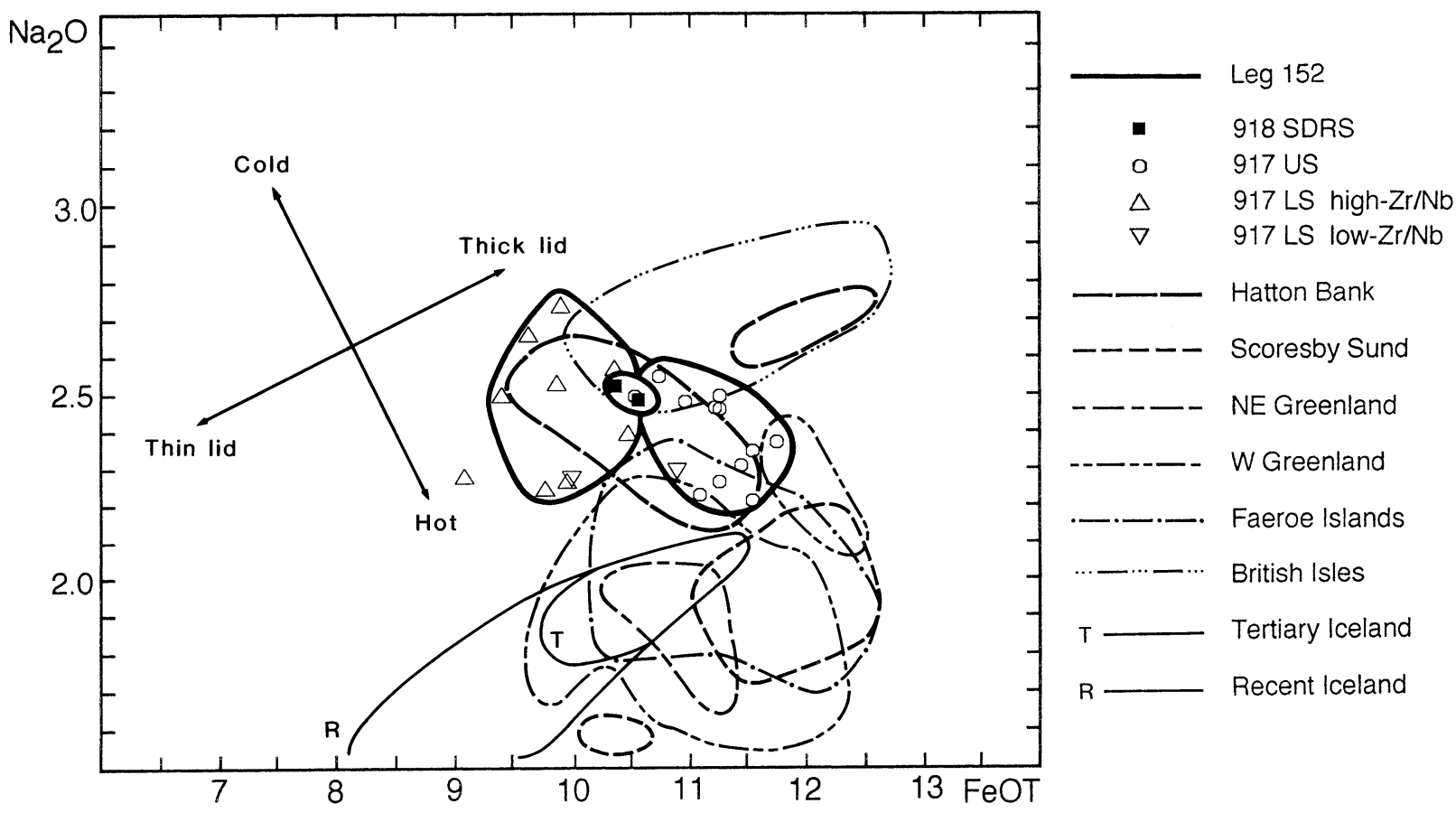

Figure 8. $\mathrm{Na}_{2} \mathrm{O}$ vs. FeOT (total iron as $\mathrm{FeO}$ ) for the North Atlantic region. The analytical values have not been normalized to a fixed $\mathrm{MgO}$ content, but only rocks with $8 \%-12 \% \mathrm{MgO}$ and less than $4.5 \%$ volatiles are plotted. Data fields for the different areas are encircled. Data from Kangerlussuaq, the Vøring Plateau, and the Rockall Trough are too scattered to allow definition of a data field. See text for discussion.

also concluded by Fram and Lesher (1993). Recent basalts from Iceland's active rift zones include rocks with very low $\mathrm{FeO}$ (Fig. 8); these are considered to be low-pressure melts from already melt-depleted mantle (Elliott et al., 1991).

Most data for the North Atlantic cluster fairly consistently in Figure 8. In some areas (e.g., West Greenland), different rock groups cluster in different fields; for clarity, close-lying and overlapping fields have been combined into one field in Figure 8. The Baffin Island field and the most Fe-poor West Greenland field overlap. The relatively low FeOT in 917LS, as compared with 917US and 918 SDRS, is ascribed to crustal assimilation. The 918 SDRS basalts have FeOT lower than in 917US but higher than in normal MORB, indicating a thinning of the lid from the 917US (breakup) series to the 918 SDRS (post-breakup) series, but still not attainment of fully normal oceanic conditions. The characteristic feature of the diagram is that the basalts from the southeast Greenland and Hatton Bank margins, together with those from the British Isles (except the Preshal Mhor type basalts), have significantly higher $\mathrm{Na}_{2} \mathrm{O}$ contents than the basalts from the other areas of the North Atlantic. The basalts from the other areas of the North Atlantic are significantly lower in $\mathrm{Na}_{2} \mathrm{O}$ than normal MORB, in accordance with the findings of Klein and Langmuir (1987) and Langmuir et al. (1992), and ascribed to hotter (plume) mantle with larger melt fractions than normally. There are some intra-group differences with the more enriched rocks generally plotting to the right and the more depleted rocks plotting to the left in the field for the area. There are no great intergroup differences; the data fields show much overlap.

Relatively higher $\mathrm{Na}_{2} \mathrm{O}$ in the melt results from relatively smaller degrees of melting (colder mantle in Figure 8). This is a viable explanation for the high $\mathrm{Na}_{2} \mathrm{O}$ in the transitional to slightly alkaline basalts of the British Isles, but it is difficult to envisage that the strongly depleted (see below) tholeiitic melts from southeast Greenland and Hatton Bank are formed by smaller degrees of melting than the other North Atlantic basalts. This is, however, the most straightforward explanation of Figure 8. If it is correct that the southeast Greenland and Hatton Bank basalts formed by lesser degrees of melting than the ba- salts in the other areas of the North Atlantic, it follows that their depleted character must be caused by melting of a more depleted mantle than in the other areas.

Figures 9 and 10 show Ce/Y vs. Zr/Nb for Leg 152 and the North Atlantic. These ratios are relatively insensitive to fractionation processes but are sensitive to both melting processes and crustal assimilation. Crustal rocks generally have much higher $\mathrm{Ce} / \mathrm{Y}$ and usually also higher $\mathrm{Zr} / \mathrm{Nb}$ than mantle melts, so that crustal assimilation will shift the affected melts upward and usually also to the right in this diagram. In the North Atlantic region, crustal assimilation has given rise to rock groups with steep trends of increasing $\mathrm{Ce} / \mathrm{Y}$ at nearly constant $\mathrm{Zr} / \mathrm{Nb}$ in southeast Greenland (917LS and 917MS), West Greenland, the Vøring Plateau, northeast Greenland, and the Rockall Trough (outside the diagram at high $\mathrm{Ce} / \mathrm{Y}$ ). A few northeast Greenland rocks with high $\mathrm{Ce} / \mathrm{Y}$ are inferred to have resulted from small melt fractions (Thirlwall et al., 1994).

However, steep $\mathrm{Ce} / \mathrm{Y}$ trends may also be produced without crustal contamination. The Faeroe Islands Lower Series basalts display such a trend with $\mathrm{Ce} / \mathrm{Y}$ up to 2.2 (Fig. 10) without any obvious crustal assimilation. High-pressure garnet and clinopyroxene fractionation, selectively removing $\mathrm{Y}$, has recently been suggested for these rocks (Bernstein, 1995). The high Ce/Y up to 2.0 in some of the apparently uncontaminated Kangerlussuaq lavas (Fig. 10) may have the same explanation.

Primary mantle melts may show a range of both $\mathrm{Ce} / \mathrm{Y}$ and $\mathrm{Zr} / \mathrm{Nb}$ values. Melts produced within the garnet stability field will have higher $\mathrm{Ce} / \mathrm{Y}$ than melts from the spinel stability field because garnet preferentially retains $\mathrm{Y}$. Further, because $\mathrm{Nb}$ is more incompatible than $\mathrm{Zr}$, melts produced by small degrees of melting will have lower $\mathrm{Zr} / \mathrm{Nb}$ than melts produced by large degrees of melting. Within a melting column the first, deep, small-degree melts will have high Ce/ $\mathrm{Y}$ and low $\mathrm{Zr} / \mathrm{Nb}$, whereas the last, shallow, high-degree melts will have low $\mathrm{Ce} / \mathrm{Y}$ and high $\mathrm{Zr} / \mathrm{Nb}$. If the melts in the melting column are incompletely pooled, they will scatter along a hyperbola between the extremes. Normal oceanic basalts produced from depleted mantle have $\mathrm{Zr} / \mathrm{Nb}$ around 30 (Sun and McDonough, 1989), and $\mathrm{Zr} / \mathrm{Nb}$ ratios 


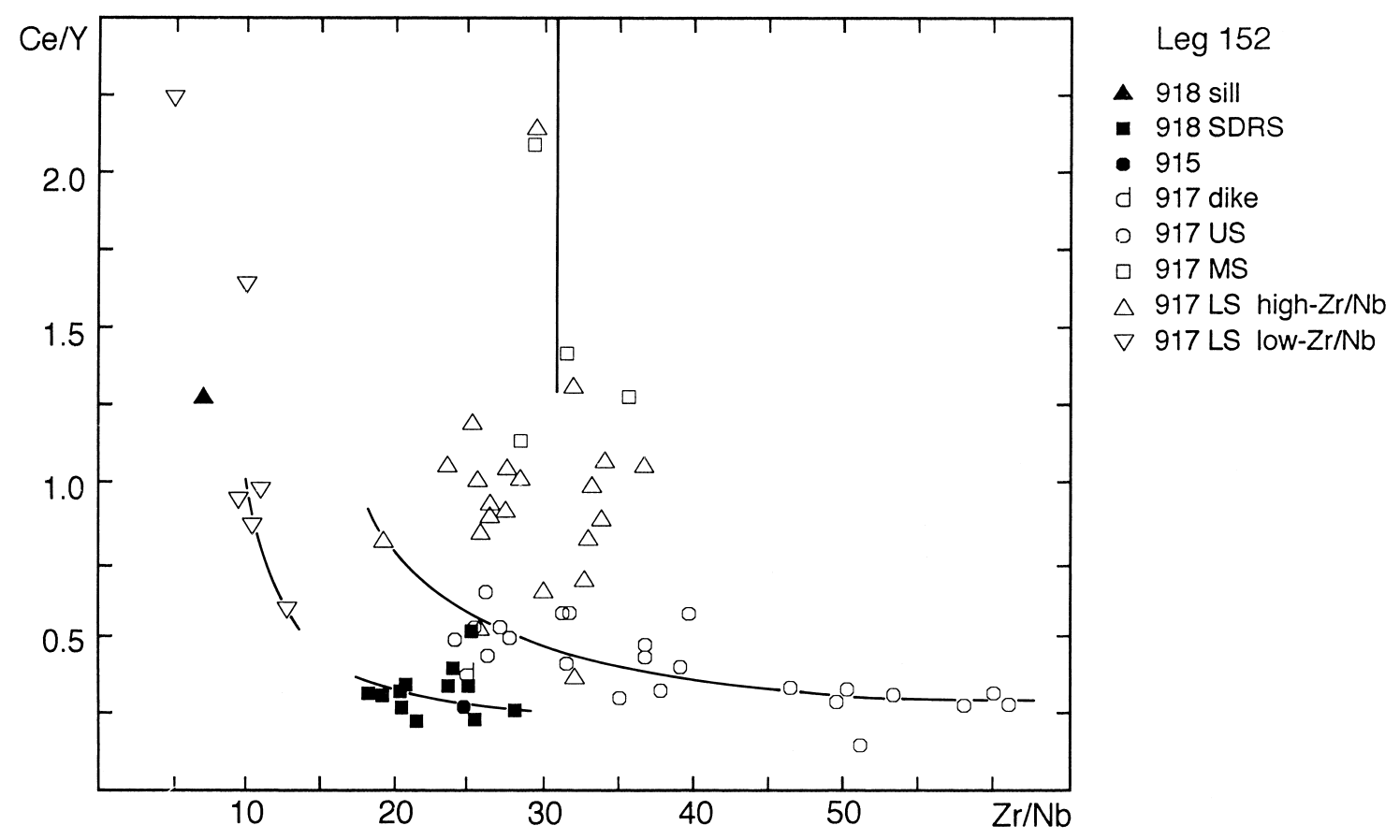

Figure 9. $\mathrm{Ce} / \mathrm{Y}$ vs. $\mathrm{Zr} / \mathrm{Nb}$ for the Leg 152 volcanic succession. Most rocks from $917 \mathrm{MS}$ have $\mathrm{Ce} / \mathrm{Y}>2.5$ and plot outside the diagram at $\mathrm{Zr} / \mathrm{Nb}$ around 30 . The basement gneiss sample has $\mathrm{Ce} / \mathrm{Y}=13.8$ and $\mathrm{Zr} / \mathrm{Nb}=32$. The four lavas from 917LS with $\mathrm{Ce} / \mathrm{Y}>1.25$ are all silica-enriched (Fig. 4; Table 1) and have clearly assimilated continental crust. The 917LS lavas with high combined $\mathrm{Ce} / \mathrm{Y}$ and $\mathrm{Zr} / \mathrm{Nb}$ are also interpreted to be contaminated (Fig. 4; Fitton et al., Chaps. 28 and 29, this volume). Four 917LS low-Zr/Nb lavas appear uncontaminated.

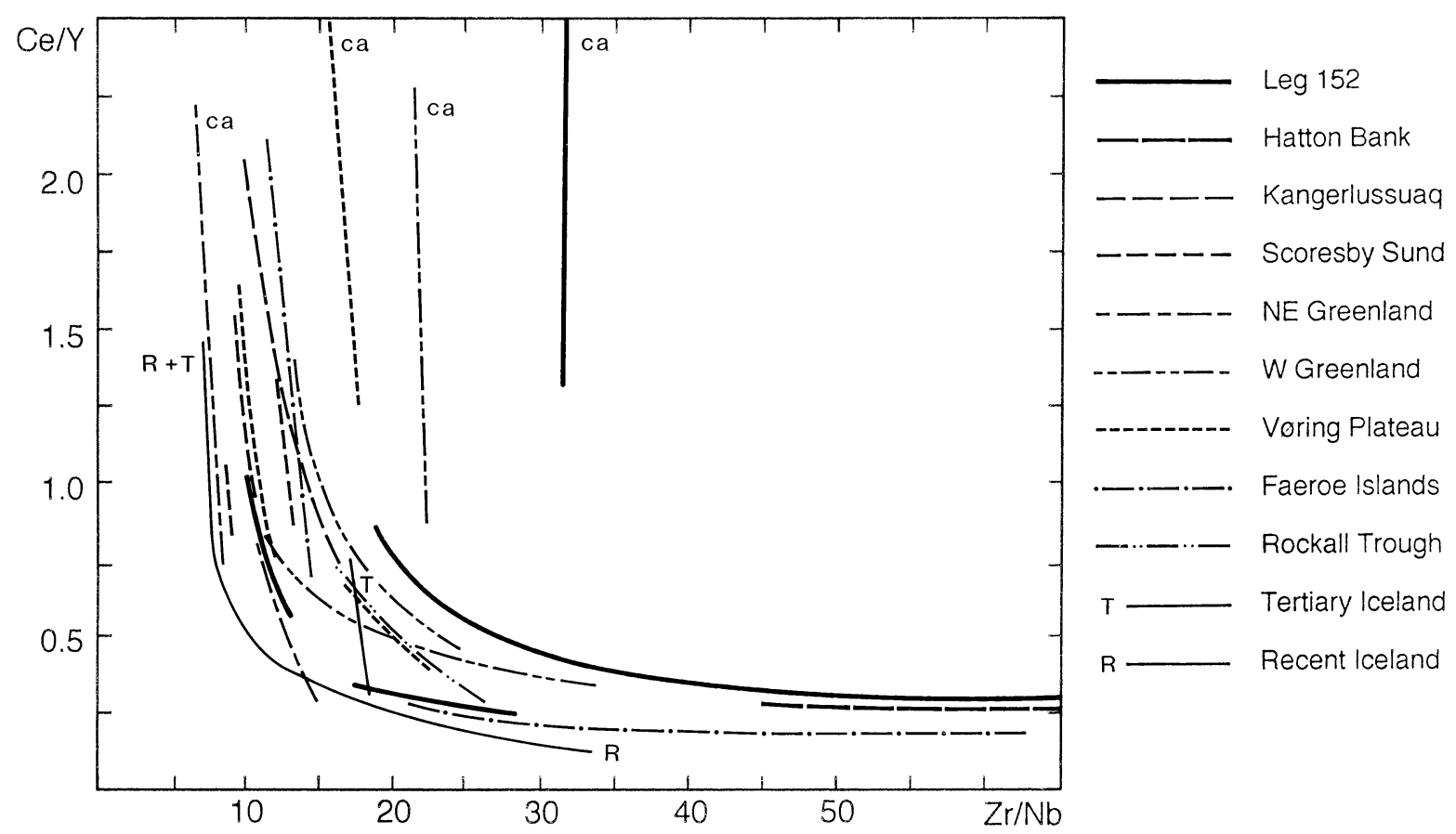

Figure 10. $\mathrm{Ce} / \mathrm{Y}$ vs. $\mathrm{Zr} / \mathrm{Nb}$ for the North Atlantic region. The large amount of data are simplified into trend lines. ca $=$ crustal assimilation trend. No trends could be defined for the British Isles because of data scatter; most of the British data have $\mathrm{Ce} / \mathrm{Y}=0.5-1.5$ and $\mathrm{Zr} / \mathrm{Nb}=10-45$. See text for discussion.

greater than this imply further depletion of the mantle, either by prior melting episodes or by incomplete melt pooling (removal of the first formed, deep liquids) in the melting column during the last melting event.

Most of the uncontaminated lavas in the North Atlantic have Ce/ $\mathrm{Y}<1.5$ (excepting the Faeroe Islands Lower Series). Individual trends can be discerned within several areas, but there are fewer individual trends in this diagram than in the $\mathrm{TiO}_{2}-\mathrm{MgO}$ diagram (Fig. 3). This suggests that some of the trends in Figure 3 are caused by different degrees of melting of the same mantle material (e.g., the two trends with different $\mathrm{TiO}_{2}$ levels in 917US). Compositional differences in the mantle will influence the position and shape of the curves 
in Figure 9. The separation of 917US and $915+918$ SDRS into two different curves indicates differences in mantle compositions. In the North Atlantic, Iceland (Tertiary and Recent form one trend) and 917US constitute two extremes in an apparent series of neighboring curves (Fig. 10). The Iceland plume can thus be regarded as one mantle end-member and the 917US mantle type as another. This other mantle is suggested to be the asthenospheric MORB mantle by Fitton et al. (Chap. 28, this volume). The positions of the 918SDRS and sill, and also the low-Zr/Nb lava group from 917LS, are close to the Iceland plume mantle, in accordance with the suggestions of Fitton et al. (Chap. 28, this volume).

$\mathrm{Zr} / \mathrm{Nb}$ ratios in uncontaminated basalts show regional variations in the North Atlantic. The Tertiary Icelandic basalts have $\mathrm{Zr} / \mathrm{Nb}$ around $6-10$, but $\mathrm{Zr} / \mathrm{Nb}$ ratios as high as 33 are found in some recent magnesian basalts and picrites. The Lower Tertiary basalts from West Greenland, East Greenland, the Vøring Plateau, and the Faeroe Islands have $\mathrm{Zr} / \mathrm{Nb}=10-20$, with values of up to 35 in some West Greenland picrites. There are no reliable $\mathrm{Nb}$ data from Baffin Island. The British Isles (not shown in Figure 10 because no trends are defined) have mostly $\mathrm{Zr} / \mathrm{Nb}=10-20$; one group of rocks with $\mathrm{Zr} / \mathrm{Nb}$ of $30-50$ also has very low $\mathrm{Nb}$, and the high $\mathrm{Zr} / \mathrm{Nb}$ may be an analytical artifact. In Leg 152 (Fig. 9), the 918 sill and the 917LS low-Zr/Nb group have "Icelandic" $\mathrm{Zr} / \mathrm{Nb}$ values of $10-15 ; 915+918$ SDRS have $\mathrm{Zr} / \mathrm{Nb}=18-28$, and in the $917 \mathrm{US} \mathrm{Zr} / \mathrm{Nb}$ range from 24 to around 60 . Very high $\mathrm{Zr} / \mathrm{Nb}$ ratios corresponding to those in 917US are found in the Hatton Bank lavas and in the depleted lavas in the Faeroe Islands Upper Series (Fig. 10). These melts must have been produced from a mantle that was more depleted than normal MORB mantle, either because of earlier melt removal or because of incomplete melt pooling during the present melting episode. For the 917US and Hatton Bank the high $\mathrm{Na}_{2} \mathrm{O}$ (Fig. 8) argues against incomplete melt pooling because high $\mathrm{Zr} / \mathrm{Nb}$ requires that the "over-represented" melts are the last fractions with high $\mathrm{Zr} / \mathrm{Nb}$ and low $\mathrm{Na}_{2} \mathrm{O}$. In contrast, the Faeroe Islands depleted basalts do have low $\mathrm{Na}_{2} \mathrm{O}$ and may be explained by incomplete melt pooling.

Figures 11 and 12 show plots of Zr vs. Sc for Leg 152 and the North Atlantic areas. The data have been simplified into trend lines, which are explicable in terms of crystal fractionation. During fractionation of olivine and plagioclase, both $\mathrm{Zr}$ and $\mathrm{Sc}$ are incompatible, and individual trends (representing different primary liquids) point away from the origin. When clinopyroxene joins the fractionating assemblage, Sc becomes compatible and the trend turns toward $\mathrm{Zr}$ enrichment at approximately constant $\mathrm{Sc}$. This steep part of the trend requires that $\mathrm{Sc}$ is more compatible than the $\mathrm{D}_{\mathrm{cpx}}=0.51$ of Ulmer (1989) suggests, and the steeply rising trends are probably an oversimplification. This could arise if rocks that are not related by crystal fractionation have been grouped together in Figure 12; contamination with Sc-poor crustal material will pull in the same direction, as seen in 917MS. With this reservation, several trends for each geographical group are distinguishable as in the $\mathrm{TiO}_{2}-\mathrm{MgO}$ plot. Sc contents above $50 \mathrm{ppm}$ are very rare and only occur in some rocks from the Tertiary of Iceland and in all rocks from Leg $152915+918$ SDRS and the Hatton Bank Margin. The trend for $915+918$ SDRS and two Hatton Bank trends are very similar and suggest olivine \pm plagioclase fractionation. $\mathrm{Zr} / \mathrm{Sc}$ ratios in these rocks are lower than in any other rocks from the North Atlantic, and this must be a primary feature of the melt. Low $\mathrm{Zr} / \mathrm{Sc}$ in a melt may be achieved by a two-stage mantle melting process. First, a high-pressure melt fraction, where garnet has retained $\mathrm{Sc}$ in the residue, has to be removed. Next, this depleted residue, which will have low $\mathrm{Zr} / \mathrm{Sc}$, has to melt at lower pressure in the spinel stability field. The melt then has to fractionate $20 \%-40 \%$ of olivine + plagioclase (Fitton et al., Chap. 28, this volume) to obtain the high Sc concentrations found.

The basalts from the Vøring Plateau, the northern representative of the three oldest SDRS drilled, do not have particularly high Sc (38-45 ppm) or low $\mathrm{Zr} / \mathrm{Sc}$ (Fig. 12). Neither do they have particularly high $\mathrm{Zr} / \mathrm{Nb}$ (Fig. 10) or high $\mathrm{Na}_{2} \mathrm{O}$, and their melting history thus ap- pears to be different from that in the southern part of the North Atlantic region. The closest similarity to the southeast Greenland Margin and Hatton Bank Margin in terms of $\mathrm{Zr} / \mathrm{Nb}$ and $\mathrm{Zr} / \mathrm{Sc}$ is shown by some depleted basalts from the Faeroes Upper Series (Figs. 10, 12). The only present-day North Atlantic basalts with high Sc contents are some samples from the Kolbeinsey Ridge, which have up to $56 \mathrm{ppm}$ Sc (Schilling et al., 1983).

The following main points can be made.

1. Most of the Lower Tertiary basalts in the North Atlantic have higher FeOT values than oceanic basalts, interpreted as the effect of melting under a continental lid. A major group has lower $\mathrm{Na}_{2} \mathrm{O}$ than oceanic basalts, interpreted as due to melting of hot (plume) mantle. A southern group (southeast Greenland, Hatton Bank, British Isles) has $\mathrm{Na}_{2} \mathrm{O}$ contents similar to those of oceanic basalts, and the mantle in this part seems to have been colder.

2. $\mathrm{Ce} / \mathrm{Y}$ and $\mathrm{Zr} / \mathrm{Nb}$ values in the North Atlantic lie on a number of individual mantle melting curves between an Iceland plume end member and a strongly depleted, suggested MORB-type end member represented by the $917 \mathrm{US}$ and Hatton Bank. The high $\mathrm{Zr} / \mathrm{Nb}$ in these two areas suggests a mantle even more depleted than normal MORB mantle.

3. Low $\mathrm{Zr} / \mathrm{Sc}$ ratios in the $915+918$ SDRS (Iceland type mantle) and Hatton Bank (MORB type mantle) suggest that two-stage melting processes took place in both mantle types, with removal of a highpressure melt and remelting at lower pressures. High Sc contents (>50 ppm) are characteristic of the SDRS in the southern part of the North Atlantic region.

\section{SUMMARY}

The basalts from Leg 152 at the southeast Greenland Margin are low-K tholeiites like most of the other basalts in the North Atlantic. However, Fe- and Ti-rich, three-phase cotectic basalts, which are characteristic of most of the other areas, are not represented in the SDRS off southeast Greenland, but the younger sill at Site 918 is FeTi-rich.

Primitive picritic melts with $\mathrm{MgO} \geq 15 \%$, requiring elevated mantle temperatures for their formation, were produced in several, widely spaced areas over the mantle plume head. These include southeast Greenland, West Greenland, Kangerlussuaq, and the British Isles.

The Tertiary North Atlantic basalts have higher FeOT than oceanic basalts, interpreted as the effect of melting under a continental lithospheric lid. Most basalts have lower $\mathrm{Na}_{2} \mathrm{O}$ than oceanic basalts, interpreted as the effect of melting of a hotter (plume) mantle. Exceptions are the basalts from Leg 152, the Hatton Bank, and the British Isles, all at the periphery of the mantle plume head.

$\mathrm{Ce} / \mathrm{Y}$ and $\mathrm{Zr} / \mathrm{Nb}$ values in the North Atlantic lie on a number of individual mantle melting curves between an Iceland plume end member and a strongly depleted, suggested MORB-type end member represented by the $917 \mathrm{US}$ and Hatton Bank. The high $\mathrm{Zr} / \mathrm{Nb}$ in these two areas suggests a mantle even more depleted than normal MORB mantle.

Low $\mathrm{Zr} / \mathrm{Sc}$ ratios in the $915+918$ SDRS (Iceland type mantle) and Hatton Bank (MORB type mantle) suggest that two-stage melting processes took place in both mantle types, with removal of a highpressure melt and remelting at lower pressures. High Sc contents $(>50 \mathrm{ppm})$ are characteristic of the SDRS in the southern part of the North Atlantic region.

All SDRS drilled up to now (Vøring Margin, Hatton Margin, southeast Greenland Margin) include crustally contaminated rocks in the oldest parts of the sequences. Thick Tertiary dacite successions formed only over the peripheral parts of the mantle plume head.

The crustal contaminant at the southeast Greenland Margin has trace element characteristics similar to those in the northwestern British Isles and to some extent Kangerlussuaq. It is in strong contrast to the crustal component in the Hatton Bank lavas. Whereas the first 


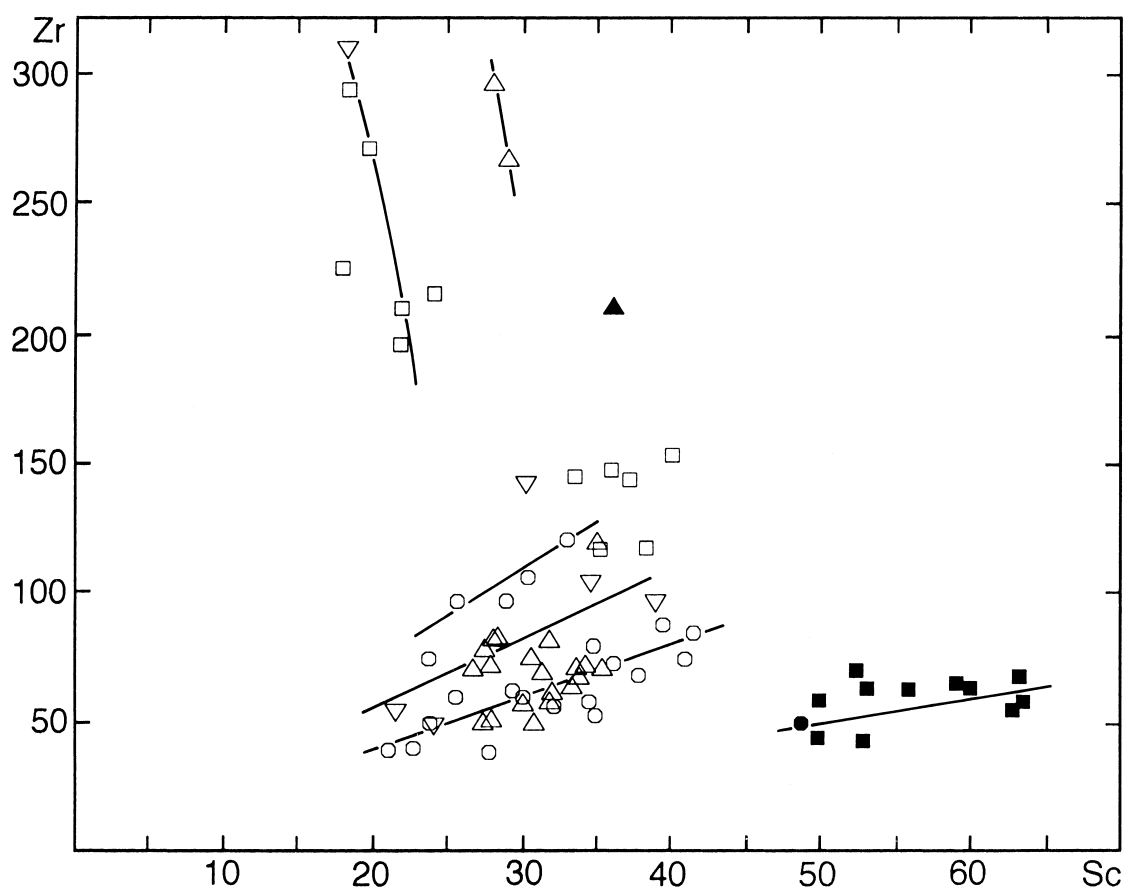

Leg 152

\ 918 sill

- 918 SDRS

- 915

d 917 dike

- 917 US

口 $917 \mathrm{MS}$

$\triangle 917$ LS high-Zr/Nb

$\nabla 917$ LS low-Zr/Nb

Figure 11. Zr vs. Sc for the Leg 152 volcanic succession.

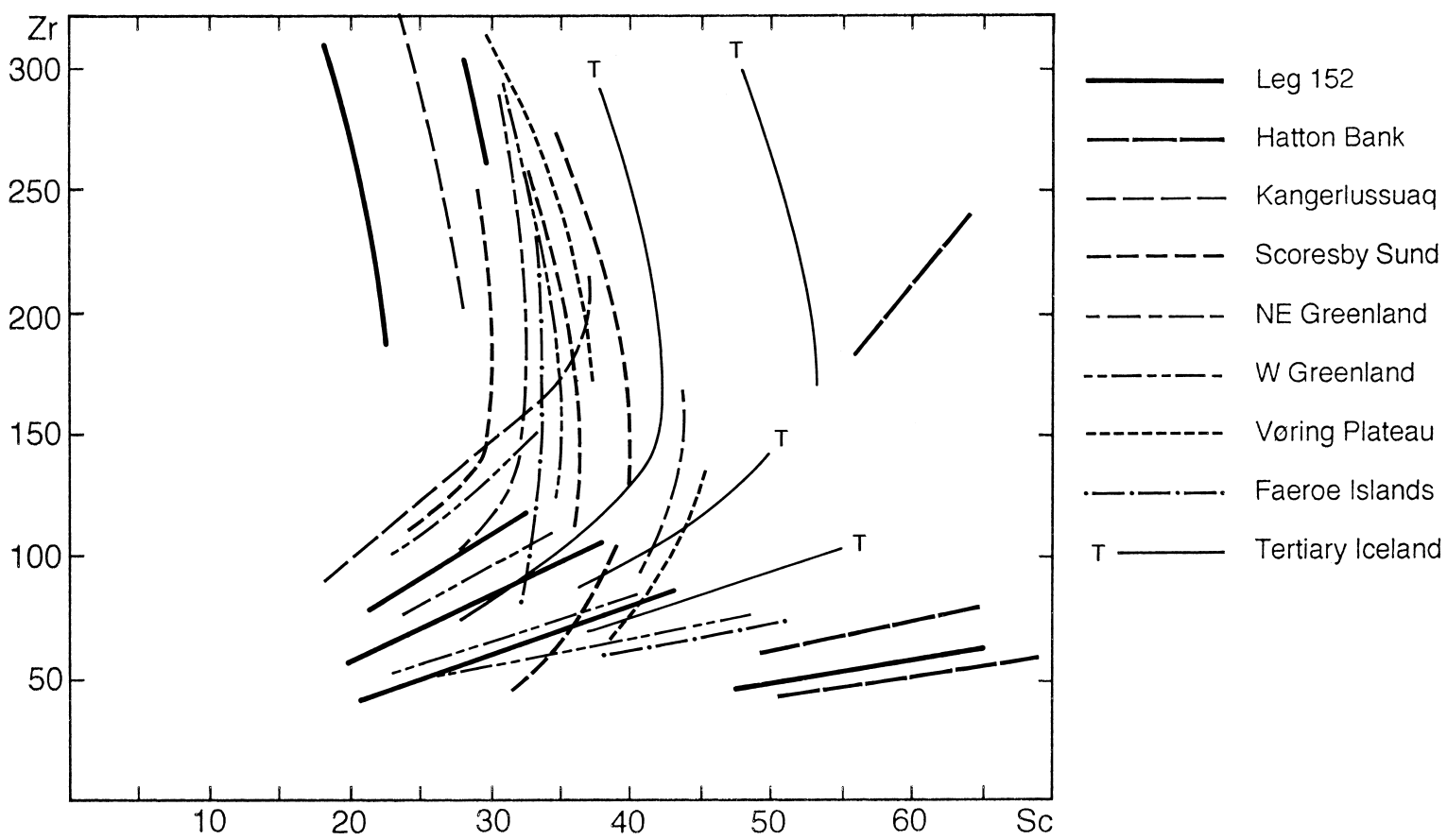

Figure 12. Zr vs. Sc for the North Atlantic region. The large amount of data are simplified into trend lines. There are no Zr plus Sc data for the Rockall Trough and the British Isles. See text for discussion.

three areas are situated within the old, partly reworked, Archaean craton that occupies much of the North Atlantic region, the Hatton Bank is underlain by Proterozoic basement.

\section{REFERENCES}

Beckinsale, R.D., Pankhurst, R.J., Skelhorn, R.R., and Walsh, J.N., 1978. Geochemistry and petrogenesis of the early Tertiary lava pile of the Isle of Mull, Scotland. Contrib. Mineral. Petrol., 66:415-427.
Bell, B.R., and Williamson, T., 1994. Picritic basalts from the Palaeocene lava field of west-central Skye, Scotland: evidence for parental magma compositions. Mineral. Mag., 58:347-356.

Bernstein, S., 1995. High-pressure fractionation in rift-related basaltic magmatism: Faeroe plateau basalts. Geology, 22:815-818.

Blichert-Toft, J., Rosing, M.T., Lesher, C.E., and Chauvel, C., 1995. Geochemical constraints on the origin of the Late Archaean Skjoldungen Alkaline Igneous Province, SE Greenland. J. Petrol., 36:515-561.

Brooks, C.K., 1973. Tertiary of Greenland - a volcanic and plutonic record of continental break-up. AAPG Mem., 19:150-160. 
Chalmers, J.A., Larsen, L.M., and Pedersen, A.K., 1995. Widespread Paleocene volcanism around the northern North Atlantic and Labrador Sea:evidence for a large, hot, early plume head. J. Geol. Soc. London, 152:965-969.

Clarke, D.B., 1968. Tertiary basalts of the Baffin Bay area [Ph.D. thesis]. Univ. of Edinburgh.

Clarke, D.B., and Pedersen, A.K., 1976. Tertiary volcanic province of West Greenland. In Escher, A., and Watt, W.S. (Eds.), Geology of Greenland. Geol. Surv. Greenl., 364-385.

Dickin, A.P., 1981. Isotope geochemistry of Tertiary igneous rocks from the Isle of Skye, N. W. Scotland. J. Petrol., 22:155-189.

_ 1992. Evidence for an Early Proterozoic crustal province in the North Atlantic region. J. Geol. Soc. London, 149:483-486.

Dickin, A.P., Jones, N.W., Thirlwall, M.F., and Thompson, R.N., 1987. A Ce/ Nd-isotope study of crustal contamination processes affecting Paleocene magmas in Skye, Northwest Scotland. Contrib. Mineral. Petrol., 96:455464.

Elliott, T.R., Hawkesworth, C.J., and Grönvold, K., 1991. Dynamic melting of the Iceland plume. Nature, 351:201-206.

Emeleus, C.H., 1985. The Tertiary lavas and sediments of northwest Rhum, Inner Hebrides. Geol. Mag., 122:419-437.

Fitton, J.G., Saunders, A.D., Larsen, L.M., Fram, M.S., Demant, A., Sinton, C., and Leg 152 Shipboard Scientific Party, 1995. Magma sources and plumbing systems during break-up of the Southeast Greenland margin: preliminary results from ODP leg 152. J. Geol. Soc. London, 152:985990.

Fram, M.S., 1994. Petrogenesis of the Early Tertiary flood basalts of the East Greenland continental margin [Ph.D. thesis]. Columbia Univ.

Fram, M.S., and Lesher, C.E., 1993. Geochemical constraints on mantle melting during creation of the North Atlantic basin. Nature, 363:712715.

- 1997. Generation and polybaric differentiation of East Greenland Early Tertiary flood basalts. J. Petrol., 38:231-275.

Francis, D., 1985. The Baffin Bay lavas and the value of picrites as analogues of primary magmas. Contrib. Mineral. Petrol., 89:144-154.

Gariépy, C., Ludden, J., and Brooks, C., 1983. Isotopic and trace element constraints on the genesis of the Faeroe lava pile. Earth Planet. Sci. Lett., 63:257-272.

Gill, R.C.O., Nielsen, T.F.D., Brooks, C.K., and Ingram, G.A., 1988. Tertiary volcanism in the Kangerdlugssuaq region, East Greenland: trace-element geochemistry of the Lower Basalts and tholeiitic dyke swarms. In Morton, A.C., and Parson, L.M. (Eds.), Early Tertiary Volcanism and the Opening of the Northeast Atlantic. Geol. Soc. Spec. Publ. London, 39:161-179.

Gill, R.C.O., Pedersen, A.K., and Larsen, J.G., 1992. Tertiary picrites in West Greenland: melting at the periphery of a plume? In Storey, B.C., Alabaster, T. and Pankhurst, R.J. (Eds.), Magmatism and the Causes of Continental Break-up. Geol. Soc. Spec. Publ. London, 68:335-348.

Hald, N., 1976. Early Tertiary flood basalts from Hareøen and western Nûgssuaq, West Greenland. Bull. Groenl. Geol. Unders., 120.

Hald, N., and Waagstein, R., 1984. Lithology and chemistry of a 2-km sequence of Lower Tertiary tholeiitic lavas drilled on Suduroy, Faeroe Islands (Lopra-1). In Berthelsen, O., Noe-Nygaard, A., and Rasmussen, J. (Eds.), The Deep Drilling Project 1980-81 in the Faeroe Islands. Ann. Soc. Sci. Færoensis, 1984:15-38.

Hansen, H., 1993. Terticere basalter på Østgrønland [cand. scient. thesis]. Univ. of Copenhagen

Hansteen, T.H., 1991. Multi-stage evolution of the picritic Mælifell rocks, SW Iceland: constraints from mineralogy and inclusions of glass and fluid in olivine. Contrib. Mineral. Petrol., 109:225-239.

Harris, A.L., 1991. The growth and structure of Scotland. In Craig, G.Y. (Ed.) Geology of Scotland. Geol. Soc. London, 1-24.

Hémond, C., Arndt, N.T., Lichtenstein, U., Hofmann, A.W., Oskarsson, N., and Steinthorsson, S., 1993. The heterogeneous Iceland plume: Nd:Sr:O isotopes and trace element constraints. J. Geophys. Res., 98:1583315850 .

Holm, P.M., 1988. Nd, Sr and Pb isotope geochemistry of the Lower Lavas, East Greenland Tertiary Igneous Province. In Morton, A.C., and Parson, L.M. (Eds.), Early Tertiary Volcanism and the Opening of the Northeast Atlantic. Geol. Soc. Spec. Publ. London, 39:181-195.

Holm, P.M., Gill, R.C.O., Pedersen, A.K., Larsen, J.G., Hald, N., Nielsen, T.F.D., and Thirlwall, M.F., 1993. The Tertiary picrites of West Greenland: contributions from "Icelandic" and other sources. Earth Planet. Sci. Lett., 115:227-244.
Holmes, A., 1918. The basaltic rocks of the Arctic region. Mineral. Mag., $18: 180-223$

Kent, R.W., 1995. Magnesian basalts from the Hebrides, Scotland: chemical composition and relationship to the Iceland plume. J. Geol. Soc. London, 152:979-983.

Klein, E.M., and Langmuir, C.H., 1987. Global correlations of ocean ridge basalt chemistry with axial depth and crustal thickness. J. Geophys. Res., 92:8089-8115.

Langmuir, C.H., Klein, E., and Plank, T., 1992. Petrological systematics of mid-ocean ridge basalts: constraints on melt generation beneath ocean ridges. In Morgan, J., Blackman, D., Sinton, J. (Eds.), Mantle Flow and Melt Generation at Mid-Ocean Ridges. Geophys. Monogr., Am. Geophys. Union, 71:183-277.

Larsen, H.C., Saunders, A.D., Clift, P.D., et al., 1994. Proc. ODP, Init. Repts., 152: College Station, TX (Ocean Drilling Program).

Larsen, L.M., and Pedersen, A.K., 1990. Volcanic marker horizons in the Maligât Formation on Disko and Nûgssuaq, and implications for the development of the southern part of the West Greenland basin in the early Tertiary. Rapp. Groenl. Geol. Unders., 148:65-73.

_ 1992. Volcanic marker horizons in the upper part of the Maligât Formation on eastern Disko and Nuussuaq, Tertiary of West Greenland: synto post-volcanic basin movements. Rapp. Groenl. Geol. Unders., 155:85-93.

Larsen, L.M., Pedersen, A.K., Pedersen, G.K., and Piasecki, S., 1992. Timing and duration of Early Tertiary volcanism in the North Atlantic: new evidence from West Greenland. In Storey, B.C., Alabaster, T., and Pankhurst, R.J. (Eds.), Magmatism and the Causes of Continental Breakup. Geol. Soc. Spec. Publ. London, 68:321-333.

Larsen, L.M., Watt, W.S., and Watt, M., 1989. Geology and petrology of the Lower Tertiary plateau basalts of the Scoresby Sund region, East Greenland. Bull.Groenl. Geol. Unders., 157:1-164.

Lawver, L.A., and Müller, R.D., 1994. Iceland hotspot track. Geology, 22:311-314.

McClurg, J.E., 1982. Petrology and evolution of the northern part of the Rhum ultrabasic complex [Ph.D. thesis]. Univ. of Edinburgh.

McKenzie, D., and Bickle, M.J., 1988. The volume and composition of melt generated by extension of the lithosphere. J. Petrol., 29:625-679.

Merriman, R.J., Taylor, P.N., and Morton, A.C., 1988. Petrochemistry and isotope geochemistry of early Palaeogene basalts forming the dipping reflector sequence SW of Rockall Plateau, NE Atlantic. In Morton, A.C., and Parson, L.M. (Eds.), Early Tertiary Volcanism and the Opening of the NE Atlantic. Geol. Soc. Spec. Publ. London, 39:123-134.

Moorbath, S., and Thompson, R.N., 1980. Strontium isotope geochemistry and petrogenesis of the early Tertiary lava pile of the Isle of Skye, Scotland, and other basic rocks of the British Tertiary Province: an example of magma-crust interaction. J. Petrol., 21:295-321.

Morton, A.C., Dixon, J.E., Fitton, J.G., Macintyre, R.M., Smythe, D.K., and Taylor, P.N., 1988. Early Tertiary volcanic rocks in Well 163/6-1A, Rockall Trough. In Morton, A.C., and Parson, L.M. (Eds.), Early Tertiary Volcanism and the Opening of the Northeast Atlantic. Geol. Soc. Spec. Publ. London, 39:293-308.

Morton, A.C., and Taylor, P.N., 1987. Lead isotope evidence for the structure of the Rockall dipping-reflector passive margin. Nature, 326:381-383.

Nielsen, T.F.D., Soper, N.J., Brooks, C.K., Faller, A.M., Higgins, A.C., and Matthews, D.W., 1981. The pre-basaltic sediments and the lower basalts at Kangerdlugssuaq, East Greenland: their stratigraphy, lithology, paleomagnetism and petrology. Medd. Groenl., Geosci., 6:1-25.

Óskarsson, N., Steinthórsson, S., and Sigvaldason, G.E., 1985. Iceland geochemical anomaly: origin, volcanotectonics, chemical fractionation and isotope evolution of the crust. J. Geophys. Res., 90:10011-10025.

Parson, L., Viereck, L., Love, D., Gibson, I., Morton, A., and Hertogen, J., 1989. The petrology of the lower series volcanics, ODP Site 642. In Eldholm, O., Thiede, J., Taylor, E., et al., Proc. ODP, Sci. Results, 104: College Station, TX (Ocean Drilling Program), 419-428.

Pedersen, A.K., 1985a. Lithostratigraphy of the Tertiary Vaigat Formation on Disko, central West Greenland. Rapp. Groenl. Geol. Unders., 124. - 1985b. Reaction between picrite magma and continental crust: early Tertiary silicic basalts and magnesian andesites from Disko, West Greenland. Bull. Groenl. Geol. Unders., 152.

Robillard, I., Francis, D., and Ludden, J.N., 1992. The relationship between E- and N-type magmas in the Baffin Bay lavas. Contrib. Mineral. Petrol., 112:230-241.

Roeder, P.L., and Emslie, R.F., 1970. Olivine-liquid equilibrium. Contrib. Mineral. Petrol., 29:275-289. 
Scarrow, J.H., and Cox, K.G., 1995. Basalts generated by decompressive adiabatic melting of a mantle plume: a case study from the Isle of Skye, NW Scotland. J. Petrol., 36:3-22.

Schilling, J.-G., Zajac, M., Evans, R., Johnston, T., White, W., Devine, J.D., and Kingsley, R., 1983. Petrologic and geochemical variations along the Mid-Atlantic ridge from $29^{\circ} \mathrm{N}$ to $73^{\circ} \mathrm{N}$. Am. J. Sci., 283:510-586.

Shipboard Scientific Party, 1994a. Site 917. In Larsen, H.C., Saunders, A.D., Clift, P.D., et al., Proc. ODP, Init. Repts., 152: College Station, TX (Ocean Drilling Program), 107-158.

-, 1994b. Summary and principal results. In Larsen, H.C., Saunders, A.D., Clift, P.D., et al., Proc. ODP, Init. Repts., 152: College Station, TX (Ocean Drilling Program), 279-292.

Sun, S.-S., and McDonough, W.F., 1989. Chemical and isotopic systematics of oceanic basalts: implications for mantle composition and processes. In Saunders, A.D., and Norry, M.J. (Eds.), Magmatism in the Ocean Basins. Geol. Soc. Spec. Publ. London, 42:313-345.

Taylor, P.N., and Morton, A.C., 1989. Sr, Nd, and Pb isotope geochemistry of the upper and lower volcanic series at Site 642. In Eldholm, O., Thiede, J., Taylor, E., et al., Proc. ODP, Sci. Results, 104: College Station, TX (Ocean Drilling Program), 429-435.

Thirlwall, M.F., Upton, B.G.J., and Jenkins, C., 1994. Interaction between continental lithosphere and the Iceland plume: $\mathrm{Sr}-\mathrm{Nd}-\mathrm{Pb}$ isotope geochemistry of Tertiary basalts, NE Greenland. J. Petrol., 35:839-879.

Thompson, R.N., Dickin, A.P., Gibson, I.L., and Morrison, M.A., 1982. Elemental fingerprints of isotopic contamination of Hebridean Palaeocene mantle-derived magmas by Archaean sial. Contrib. Mineral. Petrol., 79:159-168.

Thompson, R.N., Esson, J., and Dunham, A.C., 1972. Major element chemical variation in the Eocene lavas of the Isle of Skye, Scotland. J. Petrol., 13:219-253.

Thompson, R.N., Gibson, I.L., Marriner, G.F., Mattey, D.P., and Morrison, M.A., 1980. Trace-element evidence of multistage mantle fusion and polybaric fractional crystallization in the Palaeocene lavas of Skye, NW Scotland. J. Petrol., 21:265-293.

Thompson, R.N., Morrison, M.A., Dickin, A.P., Gibson, I.L., and Harmon, R.S., 1986. Two contrasting styles of interaction between basic magmas and continental crust in the British Tertiary Volcanic Province. J. Geophys. Res., 91:5985-5997.
Ulmer, P., 1989. Partitioning of high field strength elements among olivine, pyroxenes, garnet and calc-alkaline picrobasalt; experimental results and an application. Ann. Rep., Director Geophys. Lab., Carnegie Inst. Washington, 1988-1989, 42-47.

Upton, B.G.J., Emeleus, C.H., and Beckinsale, R.D., 1984. Petrology of the northern East Greenland Tertiary flood basalts: evidence from Hold With Hope and Wollaston Forland. J. Petrol., 25:151-184.

Viereck, L.G., Hertogen, J., Parson, L.M., Morton, A.C., Love, D., and Gibson, I.L., 1989. Chemical stratigraphy and petrology of the Vøring Plateau tholeiitic lavas and interlayered volcaniclastic sediments at ODP Hole 642E. In Eldholm, O., Thiede, J., Taylor, E., et al., Proc. ODP, Sci. Results, 104: College Station, TX (Ocean Drilling Program), 367-396.

Viereck, L.G., Taylor, P.N., Parson, L.M., Morton, A.C., Hertogen, J., Gibson, I.L., and the ODP Leg 104 Scientific Party, 1988. Origin of the Palaeogene Vøring Plateau volcanic sequence. In Morton, A.C., and Parson, L.M. (Eds.), Early Tertiary Volcanism and the Opening of the Northeast Atlantic. Geol. Soc. Spec. Publ. London, 39:69-83.

Waagstein, R., 1988. Structure, composition and age of the Faeroe basalt plateau. In Morton, A.C., and Parson, L.M. (Eds.), Early Tertiary Volcanism and the Opening of the Northeast Atlantic. Geol. Soc. Spec. Publ. London, 39:225-238.

Waagstein, R., and Hald, N., 1984. Structure and petrography of a $660 \mathrm{~m}$ lava sequence from the Vestmanna-1 drill hole, lower and middle basalt series, Faeroe Islands. In Berthelsen, O., Noe-Nygaard, A., and Rasmussen, J. (Eds.), The Deep Drilling Project 1980-81 in the Faeroe Islands. Ann. Soc. Sci. Færoensis, 1984:39-70.

Wallace, J.M., Ellam, R.M., Meighan, I.G., Lyle, P., and Rogers, N.W., 1994. $\mathrm{Sr}$ isotope data for the Tertiary lavas of Northern Ireland: evidence for open system petrogenesis. J. Geol. Soc. London, 151:869-877.

White, R., and McKenzie, D., 1989. Magmatism at rift zones: the generation of volcanic continental margins and flood basalts. J. Geophys. Res., 94:7685-7729.

Date of initial receipt: 11 September 1995

Date of acceptance: 3 July 1996

Ms 152SR-230

\section{APPENDIX}

Leg 152 Copenhagen Analytical Data

\begin{tabular}{|c|c|c|c|c|c|c|c|c|c|c|c|c|c|}
\hline Site-unit: & $915-3$ & $917-1$ & $917-2$ & $917-6$ & $917-7$ & $917-9$ & $917-10$ & $917-12$ & $917-13$ & $917-14$ & $917-16$ & $917-17$ & $917-18$ \\
\hline Series: & SDRS & Upper & Upper & Upper & Upper & Upper & Upper & Upper & Upper & Upper & Upper & Upper & Upper \\
\hline Depth: & 198.76 & 42.54 & 48.25 & 60.10 & 65.13 & 74.70 & 78.49 & 84.18 & 86.98 & 92.20 & 102.93 & 108.23 & 113.45 \\
\hline $\mathrm{SiO}_{2}$ & 49.78 & 45.03 & 44.66 & 45.05 & 44.99 & 44.95 & 46.32 & 45.24 & 46.66 & 43.38 & 43.64 & 47.45 & 47.83 \\
\hline $\mathrm{TiO}_{2}$ & 0.96 & 1.09 & 0.73 & 1.33 & 1.12 & 1.14 & 1.15 & 1.23 & 1.19 & 0.67 & 0.84 & 1.42 & 1.26 \\
\hline $\mathrm{Al}_{2} \mathrm{O}_{3}$ & 14.20 & 15.24 & 10.48 & 14.98 & 15.02 & 15.00 & 14.74 & 14.95 & 14.60 & 13.26 & 12.05 & 15.08 & 15.17 \\
\hline $\mathrm{Fe}_{2} \mathrm{O}_{3}$ & 4.49 & 8.51 & 9.30 & 6.56 & 4.86 & 4.62 & 5.51 & 6.03 & 4.81 & 4.55 & 5.30 & 5.18 & 4.27 \\
\hline $\mathrm{FeO}$ & 7.97 & 3.18 & 2.79 & 5.18 & 6.39 & 6.62 & 5.68 & 5.60 & 6.50 & 5.78 & 5.44 & 5.82 & 6.49 \\
\hline $\mathrm{MnO}$ & 0.22 & 0.18 & 0.16 & 0.22 & 0.20 & 0.18 & 0.22 & 0.20 & 0.21 & 0.19 & 0.22 & 0.19 & 0.17 \\
\hline $\mathrm{MgO}$ & 7.33 & 9.45 & 17.39 & 9.79 & 10.07 & 10.85 & 10.06 & 10.16 & 10.15 & 16.39 & 16.39 & 8.18 & 8.59 \\
\hline $\mathrm{CaO}$ & 11.08 & 8.90 & 5.95 & 9.81 & 9.84 & 8.98 & 10.03 & 9.69 & 10.36 & 7.29 & 6.73 & 10.79 & 10.75 \\
\hline $\mathrm{Na}_{2} \mathrm{O}$ & 2.08 & 2.59 & 1.62 & 2.09 & 2.33 & 2.32 & 2.37 & 2.19 & 2.14 & 1.49 & 1.64 & 2.45 & 2.41 \\
\hline $\mathrm{K}_{2} \mathrm{O}$ & 0.202 & 0.481 & 0.144 & 0.235 & 0.289 & 0.190 & 0.143 & 0.260 & 0.067 & 0.058 & 0.214 & 0.158 & 0.174 \\
\hline $\mathrm{P}_{2} \mathrm{O}_{5}$ & 0.066 & 0.059 & 0.032 & 0.071 & 0.066 & 0.065 & 0.063 & 0.061 & 0.066 & 0.017 & 0.041 & 0.100 & 0.081 \\
\hline $\mathrm{H}_{2} \mathrm{O}_{5}$ & 1.47 & 4.75 & 5.71 & 4.23 & 4.37 & 4.29 & 3.23 & 3.79 & 3.06 & 6.53 & 7.29 & 2.44 & 2.53 \\
\hline $\mathrm{CO}_{2}$ & 0.037 & 0.040 & 0.194 & 0.029 & 0.095 & 0.048 & 0.062 & 0.033 & 0.037 & 0.081 & 0.055 & 0.040 & 0.026 \\
\hline Sum & 99.87 & 99.49 & 99.15 & 99.54 & 99.63 & 99.23 & 99.55 & 99.45 & 99.82 & 99.67 & 99.84 & 99.27 & 99.74 \\
\hline $\mathrm{Rb}$ & 2.6 & 3.3 & 1.9 & 1.6 & 2.0 & 1.2 & 0.3 & 1.2 & 0.0 & 0.4 & 1.6 & 0.5 & 0.6 \\
\hline $\mathrm{Ba}$ & 33 & 63 & 20 & 24 & 82 & 45 & 9 & 16 & 6 & 7 & 35 & 70 & 78 \\
\hline $\mathrm{Pb}$ & 1 & 1 & 2 & 2 & 4 & 1 & 0 & 1 & 1 & 1 & 4 & 2 & 1 \\
\hline $\mathrm{Sr}$ & 73 & 192 & 72 & 142 & 142 & 135 & 125 & 139 & 124 & 51 & 191 & 147 & 139 \\
\hline $\mathrm{La}$ & 4 & 5 & 5 & 4 & 4 & 3 & 4 & 4 & 2 & 3 & 4 & 7 & 7 \\
\hline $\mathrm{Ce}$ & 7 & 11 & 4 & 8 & 8 & 8 & 8 & 8 & 7 & 4 & 7 & 17 & 14 \\
\hline $\mathrm{Nd}$ & 5 & 9 & 4 & 7 & 7 & 7 & 6 & 7 & 6 & 1 & 6 & 13 & 12 \\
\hline $\mathrm{Y}$ & 28 & 26 & 14 & 26 & 25 & 24 & 21 & 24 & 24 & 19 & 18 & 28 & 25 \\
\hline Th & 0 & 0 & 0 & 0 & 0 & 0 & 0 & 0 & 0 & 0 & 1 & 1 & 0 \\
\hline $\mathrm{Zr}$ & 49 & 59 & 39 & 65 & 56 & 53 & 55 & 59 & 57 & 32 & 45 & 83 & 74 \\
\hline $\mathrm{Nb}$ & 2.0 & 1.5 & 1.0 & 1.1 & 0.9 & 1.0 & 0.9 & 1.2 & 1.2 & 0.6 & 0.9 & 2.1 & 2.3 \\
\hline $\mathrm{Zn}$ & 101 & 89 & 93 & 86 & 85 & 87 & 82 & 86 & 82 & 68 & 75 & 89 & 91 \\
\hline $\mathrm{Cu}$ & 97 & 118 & 76 & 147 & 60 & 84 & 77 & 123 & 125 & 71 & 151 & 97 & 81 \\
\hline Co & 66 & 81 & 120 & 57 & 65 & 64 & 65 & 65 & 60 & 79 & 83 & 54 & 56 \\
\hline $\mathrm{Ni}$ & 76 & 362 & 1417 & 150 & 201 & 232 & 239 & 204 & 222 & 645 & 765 & 135 & 165 \\
\hline $\mathrm{Sc}$ & 58 & 35 & 23 & 41 & 35 & 35 & 36 & 40 & 34 & 32 & 30 & 48 & 41 \\
\hline $\mathrm{V}$ & 322 & 313 & 164 & 310 & 282 & 279 & 274 & 281 & 266 & 209 & 197 & 350 & 310 \\
\hline $\mathrm{Cr}$ & 137 & 792 & 1581 & 317 & 388 & 413 & 451 & 391 & 411 & 1116 & 1343 & 295 & 319 \\
\hline $\mathrm{Ga}$ & 19 & 18 & 14 & 20 & 18 & 20 & 19 & 19 & 20 & 15 & 15 & 20 & 19 \\
\hline
\end{tabular}

Notes: Depths in meters below seafloor. SDRS = lavas in the oceanic part of the seaward-dipping reflector sequence. Major elements in weight $\%$, trace elements in ppm. Major element analyses except $\mathrm{Na}_{2} \mathrm{O}$ by XRF at the Geological Survey of Greenland; $\mathrm{Na}_{2} \mathrm{O}$ by AAS, and $\mathrm{FeO}$ by titration; analyst $\mathrm{J}$. $\mathrm{Kystol}_{2} \mathrm{H}_{2} \mathrm{O}$ and $\mathrm{CO} \mathrm{C}_{2}$ by $\mathrm{CHN}$ analyzer, analyst $\mathrm{P}$. Hansen, H.C. Ørsted Institute, University of Copenhagen. Trace element analyses by XRF, analyst J. Bailey, Institute of Geology, University of Copenhagen. 
APPENDIX (continued).

\begin{tabular}{|c|c|c|c|c|c|c|c|c|c|c|c|c|c|}
\hline Site-unit: & 917-19 & $917-21$ & $917-24$ & $917-25$ & $917-26$ & $917-27$ & $917-30$ & $917-31 \mathrm{~A}$ & $917-31 B$ & $917-32$ & $917-33$ & $917-34$ & $917-36$ \\
\hline Series: & Upper & Upper & Upper & Upper & Upper & Upper & Upper & Upper & Upper & Upper & Upper & Middle & Middle \\
\hline Depth: & 120.65 & 131.77 & 141.33 & 149.47 & 151.08 & 153.77 & 157.16 & 160.14 & 164.92 & 170.03 & 177.79 & 193.20 & 207.27 \\
\hline $\mathrm{SiO}_{2}$ & 46.04 & 44.17 & 46.59 & 44.82 & 46.79 & 44.74 & 44.94 & 44.32 & 43.68 & 43.59 & 46.77 & 49.39 & 52.37 \\
\hline $\mathrm{TiO}_{2}$ & 1.47 & 1.16 & 1.43 & 1.65 & 1.91 & 1.75 & 1.74 & 1.83 & 1.40 & 0.74 & 1.41 & 2.59 & 1.23 \\
\hline $\mathrm{Al}_{2} \mathrm{O}_{3}$ & 14.56 & 11.17 & 15.20 & 12.26 & 13.62 & 13.16 & 12.88 & 12.80 & 11.25 & 10.54 & 14.36 & 13.68 & 14.96 \\
\hline $\mathrm{Fe}_{2}^{2} \mathrm{O}_{3}$ & 5.36 & 5.57 & 6.38 & 5.89 & 5.24 & 6.77 & 7.75 & 7.94 & 7.22 & 4.55 & 7.74 & 5.93 & 6.24 \\
\hline $\mathrm{FeO}$ & 6.42 & 5.58 & 5.25 & 6.43 & 6.65 & 5.44 & 4.62 & 4.74 & 4.94 & 5.84 & 3.85 & 8.09 & 4.93 \\
\hline $\mathrm{MnO}$ & 0.20 & 0.20 & 0.18 & 0.21 & 0.18 & 0.19 & 0.21 & 0.23 & 0.19 & 0.19 & 0.23 & 0.24 & 0.18 \\
\hline $\mathrm{MgO}$ & 9.48 & 14.47 & 8.02 & 13.03 & 9.03 & 10.87 & 11.79 & 11.58 & 16.05 & 22.21 & 8.46 & 4.85 & 4.99 \\
\hline $\mathrm{CaO}$ & 10.52 & 6.22 & 11.27 & 7.96 & 9.89 & 9.21 & 8.32 & 7.99 & 6.72 & 6.62 & 9.51 & 9.38 & 8.11 \\
\hline $\mathrm{Na}_{2} \mathrm{O}$ & 2.25 & 2.18 & 2.40 & 1.77 & 2.26 & 2.03 & 1.95 & 2.25 & 1.56 & 1.17 & 2.14 & 3.26 & 3.23 \\
\hline $\mathrm{K}_{2} \mathrm{O}$ & 0.147 & 0.202 & 0.147 & 0.127 & 0.207 & 0.196 & 0.242 & 0.188 & 0.176 & 0.117 & 0.956 & 0.540 & 1.061 \\
\hline $\mathrm{P}_{2}^{2} \mathrm{O}_{5}$ & 0.086 & 0.086 & 0.071 & 0.131 & 0.162 & 0.138 & 0.135 & 0.134 & 0.103 & 0.039 & 0.083 & 0.213 & 0.148 \\
\hline $\mathrm{H}_{2} \mathrm{O}$ & 3.05 & 8.37 & 2.53 & 4.91 & 3.05 & 4.44 & 4.97 & 5.30 & 6.03 & 3.85 & 3.91 & 1.41 & 2.00 \\
\hline $\mathrm{CO}_{2}$ & 0.048 & 0.062 & 0.059 & 0.048 & 0.282 & 0.440 & 0.070 & 0.070 & 0.077 & 0.055 & 0.026 & 0.048 & 0.044 \\
\hline Sum & 99.63 & 99.42 & 99.50 & 99.22 & 99.28 & 99.36 & 99.63 & 99.34 & 99.36 & 99.47 & 99.41 & 99.59 & 99.45 \\
\hline $\mathrm{Rb}$ & 0.7 & 2.4 & 1.2 & 2.2 & 2.6 & 5.4 & 7.2 & 2.5 & 5.5 & 3.0 & 7.5 & 8.1 & 32.2 \\
\hline $\mathrm{Ba}$ & 16 & 37 & 22 & 28 & 38 & 33 & 37 & 54 & 23 & 42 & 159 & 362 & 454 \\
\hline $\mathrm{Pb}$ & 2 & 0 & 0 & 3 & 3 & 2 & 1 & 3 & 2 & 3 & 2 & 7 & 8 \\
\hline $\mathrm{Sr}$ & 138 & 124 & 163 & 123 & 159 & 141 & 130 & 120 & 98 & 86 & $14 \overline{5}$ & 336 & 449 \\
\hline $\mathrm{La}$ & 5 & 3 & 1 & 7 & 7 & 7 & 6 & 6 & 6 & 2 & 4 & 22 & 33 \\
\hline $\mathrm{Ce}$ & 12 & 6 & 11 & 13 & 17 & 16 & 15 & 20 & 11 & 6 & 13 & 44 & 67 \\
\hline $\mathrm{Nd}$ & 11 & 6 & 11 & 11 & 15 & 15 & 14 & 15 & 10 & 3 & 9 & 26 & 32 \\
\hline $\mathrm{Y}$ & 27 & 21 & 24 & 29 & 34 & 31 & 29 & 33 & 23 & 12 & 23 & 39 & 26 \\
\hline Th & 0 & 0 & 0 & 0 & 1 & 0 & 0 & 0 & 0 & 0 & 0 & 3 & 3 \\
\hline $\mathrm{Zr}$ & 73 & 66 & 73 & 90 & 123 & 96 & 93 & 104 & 72 & 39 & 76 & 147 & 134 \\
\hline $\mathrm{Nb}$ & 2.0 & 1.9 & 2.0 & 3.7 & 4.4 & 3.8 & 3.4 & 4.0 & 2.7 & 1.2 & 2.4 & 5.2 & 4.5 \\
\hline $\mathrm{Zn}$ & 87 & 94 & 83 & 96 & 91 & 96 & 94 & 104 & 87 & 73 & 90 & 118 & 106 \\
\hline $\mathrm{Cu}$ & 101 & 67 & 103 & 98 & 175 & 90 & 124 & 99 & 105 & 83 & 140 & 43 & 44 \\
\hline Co & 57 & 95 & 56 & 74 & 59 & 64 & 65 & 66 & 84 & 99 & 53 & 48 & 49 \\
\hline $\mathrm{Ni}$ & 154 & 994 & 133 & 502 & 313 & 350 & 407 & 383 & 818 & 1074 & 145 & 27 & 33 \\
\hline $\mathrm{Sc}$ & 46 & 28 & 45 & 31 & 34 & 32 & 33 & 35 & 29 & 25 & 44 & 44 & 34 \\
\hline $\mathrm{V}$ & 362 & 224 & 338 & 310 & 368 & 333 & 329 & 356 & 255 & 170 & 332 & 564 & 314 \\
\hline $\mathrm{Cr}$ & 329 & 1203 & 296 & 702 & 522 & 529 & 600 & 632 & 985 & 1641 & 321 & 36 & 24 \\
\hline $\mathrm{Ga}$ & 20 & 11 & 21 & 19 & 20 & 20 & 20 & 21 & 17 & 14 & 20 & 27 & 23 \\
\hline
\end{tabular}

APPENDIX (continued).

\begin{tabular}{|c|c|c|c|c|c|c|c|c|c|c|c|c|c|c|}
\hline Site-unit & $917-38$ & $917-39$ & $917-41$ & $917-43$ & $917-44$ & $917-45$ & $917-47$ & $917-49$ & $917-50$ & $917-52$ & $917-54$ & $917-56$ & $917-57$ & $917-58$ \\
\hline Series & Middle & Middle & Middle & Middle & Middle & Middle & Middle & Middle & Middle & Middle & Middle & Middle & Middle & Lower \\
\hline Depth & 212.10 & 213.10 & 217.32 & 230.64 & 233.17 & 235.97 & 244.16 & 260.87 & 264.93 & 296.02 & 348.67 & 375.50 & 376.30 & 390.11 \\
\hline $\mathrm{SiO}_{2}$ & 51.89 & 49.89 & 51.98 & 52.68 & 56.35 & 57.75 & 59.00 & 53.84 & 50.61 & 51.57 & 61.46 & 62.55 & 64.13 & 48.59 \\
\hline $\mathrm{TiO}_{2}$ & 1.27 & 0.83 & 1.19 & 1.29 & 1.13 & 1.12 & 1.01 & 1.24 & 1.44 & 1.43 & 0.78 & 1.29 & 1.15 & 1.08 \\
\hline $\mathrm{Al}_{2} \mathrm{O}_{3}$ & 15.40 & 13.83 & 15.26 & 14.60 & 14.87 & 14.44 & 15.22 & 14.95 & 16.00 & 14.60 & 14.91 & 13.42 & 13.17 & 15.74 \\
\hline $\mathrm{Fe}_{2} \mathrm{O}_{3}$ & 5.97 & 5.95 & 7.40 & 4.57 & 4.35 & 3.75 & 3.06 & 5.03 & 5.68 & 5.06 & 3.51 & 8.29 & 5.40 & 3.69 \\
\hline $\mathrm{FeO}$ & 4.99 & 5.91 & 3.91 & 6.86 & 5.01 & 5.43 & 4.34 & 6.08 & 4.46 & 6.49 & 2.10 & 0.88 & 2.16 & 5.30 \\
\hline $\mathrm{MnO}$ & 0.16 & 0.18 & 0.14 & 0.26 & 0.16 & 0.18 & 0.15 & 0.22 & 0.33 & 0.20 & 0.15 & 0.11 & 0.15 & 0.17 \\
\hline $\mathrm{MgO}$ & 5.64 & 7.31 & 5.45 & 5.96 & 3.73 & 3.28 & 2.97 & 4.42 & 6.25 & 5.76 & 3.74 & 1.69 & 1.76 & 6.77 \\
\hline $\mathrm{CaO}$ & 7.42 & 11.82 & 7.09 & 8.02 & 5.75 & 5.45 & 4.99 & 6.48 & 9.56 & 9.10 & 4.68 & 4.01 & 3.34 & 12.43 \\
\hline $\mathrm{Na}_{2} \mathrm{O}$ & 3.57 & 2.05 & 3.33 & 3.09 & 3.70 & 4.03 & 4.07 & 3.70 & 3.39 & 3.24 & 3.66 & 4.11 & 4.19 & 2.68 \\
\hline $\mathrm{K}_{2} \mathrm{O}$ & 0.743 & 0.495 & 0.715 & 0.475 & 1.062 & 1.452 & 1.346 & 0.695 & 0.214 & 0.694 & 2.017 & 2.862 & 2.873 & 0.186 \\
\hline $\mathrm{P}_{2} \mathrm{O}_{5}$ & 0.185 & 0.036 & 0.140 & 0.148 & 0.287 & 0.286 & 0.275 & 0.272 & 0.150 & 0.136 & 0.036 & 0.313 & 0.280 & 0.093 \\
\hline $\mathrm{H}_{2} \mathrm{O}$ & 1.95 & 1.37 & 2.43 & 1.48 & 2.94 & 2.10 & 3.03 & 2.61 & 1.61 & 1.33 & 2.39 & 0.94 & 1.03 & 1.38 \\
\hline $\mathrm{CO}_{2}$ & 0.081 & 0.070 & 0.084 & 0.051 & 0.095 & 0.055 & 0.055 & 0.066 & 0.040 & 0.037 & 0.095 & 0.033 & 0.051 & 1.400 \\
\hline Sum & 99.23 & 99.71 & 99.11 & 99.48 & 99.43 & 99.31 & 99.52 & 99.61 & 99.72 & 99.60 & 99.52 & 100.49 & 99.66 & 99.49 \\
\hline $\mathrm{Rb}$ & 9.5 & 27.2 & 9.8 & 7.5 & 21.4 & 30.6 & 29.1 & 10.2 & 1.1 & 12.2 & 14.1 & 44.0 & 49.7 & 0.5 \\
\hline $\mathrm{Ba}$ & 536 & 17 & 611 & 631 & 694 & 904 & 771 & 632 & 222 & 323 & 1161 & 1261 & 1301 & 158 \\
\hline $\mathrm{Pb}$ & 6 & 1 & 8 & 7 & 9 & 10 & 9 & 7 & 5 & 4 & 13 & 12 & 12 & 1 \\
\hline $\mathrm{Sr}$ & 434 & 68 & 448 & 359 & 523 & 514 & 532 & 566 & 410 & 349 & 132 & 404 & 344 & 314 \\
\hline $\mathrm{La}$ & 30 & 4 & 34 & 27 & 46 & 49 & 52 & 43 & 19 & 16 & 61 & 54 & 52 & 8 \\
\hline $\mathrm{Ce}$ & 61 & 9 & 61 & 50 & 92 & 97 & 103 & 77 & 37 & 33 & 120 & 101 & 103 & 17 \\
\hline $\mathrm{Nd}$ & 29 & 7 & 31 & 26 & 43 & 42 & 45 & 39 & 22 & 20 & 56 & 50 & 48 & 12 \\
\hline $\mathrm{Y}$ & 23 & 26 & 21 & 24 & 23 & 21 & 22 & 21 & 27 & 25 & 37 & 29 & 27 & 19 \\
\hline Th & 5 & 0 & 3 & 1 & 4 & 4 & 3 & 1 & 2 & 2 & 4 & 3 & 6 & 1 \\
\hline $\mathrm{Zr}$ & 138 & 37 & 143 & 147 & 203 & 201 & 236 & 191 & 114 & 97 & 366 & 256 & 274 & 60 \\
\hline $\mathrm{Nb}$ & 4.4 & 1.5 & 5.2 & 5.0 & 6.5 & 6.7 & 7.0 & 6.2 & 3.6 & 2.7 & 11.4 & 8.3 & 8.9 & 2.2 \\
\hline $\mathrm{Zn}$ & 98 & 91 & 85 & 102 & 99 & 109 & 96 & 110 & 103 & 103 & 110 & 108 & 127 & 72 \\
\hline $\mathrm{Cu}$ & 73 & 56 & 65 & 99 & 22 & 19 & 26 & 33 & 199 & 70 & 45 & 19 & 14 & 101 \\
\hline Co & 46 & 60 & 58 & 50 & 34 & 34 & 32 & 45 & 66 & 62 & 25 & 33 & 28 & 53 \\
\hline $\mathrm{Ni}$ & 38 & 68 & 73 & 45 & 15 & 11 & 14 & 20 & 50 & 47 & 43 & 12 & 12 & 138 \\
\hline $\mathrm{Sc}$ & 39 & 57 & 38 & 39 & 22 & 23 & 19 & 25 & 47 & 41 & 26 & 23 & 20 & 36 \\
\hline V & 304 & 318 & 268 & 297 & 213 & 249 & 173 & 281 & 369 & 266 & 143 & 157 & 169 & 276 \\
\hline $\mathrm{Cr}$ & 35 & 134 & 35 & 25 & 14 & 10 & 19 & 17 & 25 & 21 & 86 & 10 & 10 & 253 \\
\hline $\mathrm{Ga}$ & 22 & 17 & 21 & 21 & 21 & 23 & 22 & 21 & 23 & 24 & 18 & 21 & 22 & 20 \\
\hline
\end{tabular}


APPENDIX (continued).

\begin{tabular}{|c|c|c|c|c|c|c|c|c|c|c|c|c|c|c|}
\hline Site-unit & $917-60$ & $917-61$ & $917-62$ & $917-63$ & $917-66$ & $917-68$ & $917-70$ & $917-71$ & $917-72$ & $917-73 \mathrm{~A}$ & $917-75$ & $917-76$ & $917-78$ & $917-79$ \\
\hline Series & Lower & Lower & Lower & Lower & Lower & Lower & Lower & Lower & Lower & Lower & Lower & Lower & Lower & Lower \\
\hline Depth & 398.22 & 416.42 & 421.54 & 424.74 & 451.68 & 472.59 & 503.65 & 521.49 & 542.03 & 547.87 & 582.02 & 597.88 & 607.15 & 618.67 \\
\hline $\mathrm{SiO}_{2}$ & 47.84 & 44.01 & 44.22 & 48.03 & 49.73 & 48.16 & 50.67 & 51.60 & 51.26 & 45.05 & 53.00 & 46.95 & 47.65 & 48.23 \\
\hline $\mathrm{TiO}_{2}$ & 1.48 & 0.94 & 0.90 & 0.92 & 1.18 & 1.30 & 1.43 & 1.17 & 2.07 & 1.42 & 2.00 & 1.03 & 0.79 & 1.09 \\
\hline $\mathrm{Al}_{2} \mathrm{O}_{3}$ & 14.66 & 12.93 & 15.51 & 15.25 & 15.65 & 15.34 & 15.18 & 15.36 & 15.63 & 13.29 & 13.55 & 16.34 & 14.22 & 16.02 \\
\hline $\mathrm{Fe}_{2}^{2} \mathrm{O}_{3}$ & 4.16 & 3.95 & 4.15 & 4.74 & 5.29 & 3.68 & 5.81 & 4.40 & 8.34 & 4.79 & 6.19 & 3.94 & 3.95 & 4.28 \\
\hline $\mathrm{FeO}$ & 7.05 & 6.59 & 5.53 & 5.32 & 4.72 & 6.50 & 4.46 & 5.11 & 1.59 & 6.47 & 7.43 & 4.35 & 5.76 & 5.76 \\
\hline $\mathrm{MnO}$ & 0.18 & 0.18 & 0.16 & 0.19 & 0.17 & 0.19 & 0.16 & 0.16 & 0.17 & 0.21 & 0.21 & 0.16 & 0.20 & 0.18 \\
\hline $\mathrm{MgO}$ & 8.80 & 15.58 & 12.39 & 8.49 & 7.25 & 8.59 & 5.43 & 6.95 & 4.71 & 11.57 & 3.70 & 6.54 & 11.60 & 8.06 \\
\hline $\mathrm{CaO}$ & 11.42 & 8.51 & 9.13 & 10.84 & 10.91 & 10.81 & 10.06 & 9.73 & 7.59 & 9.43 & 6.93 & 10.08 & 9.22 & 9.63 \\
\hline $\mathrm{Na}_{2} \mathrm{O}$ & 2.24 & 1.47 & 2.07 & 2.42 & 2.69 & 2.20 & 3.15 & 2.97 & 3.87 & 1.79 & 3.76 & 2.74 & 2.00 & 2.62 \\
\hline $\mathrm{K}_{2} \mathrm{O}$ & 0.153 & 0.162 & 0.440 & 0.120 & 0.234 & 0.359 & 0.728 & 0.558 & 1.953 & 0.264 & 0.650 & 0.263 & 0.102 & 0.325 \\
\hline $\mathrm{P}_{2} \mathrm{O}_{5}$ & 0.128 & 0.096 & 0.086 & 0.065 & 0.098 & 0.141 & 0.193 & 0.129 & 0.486 & 0.098 & 0.375 & 0.120 & 0.109 & 0.129 \\
\hline $\mathrm{H}_{2} \mathrm{O}$ & 1.59 & 4.86 & 5.00 & 2.50 & 1.30 & 2.18 & 1.42 & 1.17 & 1.39 & 5.08 & 1.38 & 6.93 & 3.80 & 3.15 \\
\hline $\mathrm{CO}_{2}$ & 0.121 & 0.575 & 0.088 & 0.623 & 0.253 & 0.081 & 0.755 & 0.330 & 0.117 & 0.073 & 0.070 & 0.099 & 0.081 & 0.055 \\
\hline Sum & 99.85 & 99.81 & 99.65 & 99.50 & 99.44 & 99.51 & 99.44 & 99.61 & 99.16 & 99.51 & 99.24 & 99.54 & 99.49 & 99.51 \\
\hline $\mathrm{Rb}$ & 1.1 & 2.1 & 8.4 & 0.4 & 1.0 & 3.7 & 5.9 & 3.5 & 41.8 & 5.9 & 7.2 & 2.6 & 0.5 & 1.3 \\
\hline $\mathrm{Ba}$ & 72 & 82 & 739 & 118 & 153 & 176 & 426 & 333 & 683 & 868 & 774 & 246 & 155 & 258 \\
\hline $\mathrm{Pb}$ & 2 & 3 & 0 & 3 & 2 & 4 & 5 & 4 & 3 & 0 & 9 & 4 & 3 & 1 \\
\hline $\mathrm{Sr}$ & 185 & 158 & 316 & 245 & 273 & 226 & 330 & 278 & 352 & 190 & 411 & 573 & 270 & 403 \\
\hline $\mathrm{La}$ & 7 & 7 & 6 & 8 & 7 & 13 & 21 & 13 & 43 & 6 & 40 & 11 & 10 & 11 \\
\hline $\mathrm{Ce}$ & 14 & 12 & 14 & 16 & 14 & 22 & 43 & 30 & 81 & 8 & 83 & 22 & 23 & 22 \\
\hline $\mathrm{Nd}$ & 11 & 7 & 8 & 9 & 13 & 15 & 24 & 18 & 41 & 11 & 45 & 15 & 11 & 15 \\
\hline Y & 24 & 14 & 15 & 18 & 22 & 21 & 27 & 23 & 36 & 23 & 40 & 24 & 18 & 23 \\
\hline Th & 0 & 0 & 0 & 0 & 0 & 2 & 2 & 1 & 5 & 0 & 0 & 0 & 2 & 0 \\
\hline $\mathrm{Zr}$ & 88 & 50 & 49 & 55 & 70 & 101 & 142 & 119 & 289 & 70 & 252 & 75 & 50 & 80 \\
\hline $\mathrm{Nb}$ & 6.8 & 4.8 & 5.0 & 1.6 & 2.3 & 9.2 & 14.1 & 3.7 & 56.1 & 2.2 & 8.6 & 2.8 & 2.0 & 3.1 \\
\hline $\mathrm{Zn}$ & 80 & 74 & 67 & 83 & 82 & 79 & 84 & 89 & 100 & 75 & 141 & 83 & 76 & 83 \\
\hline $\mathrm{Cu}$ & 106 & 54 & 91 & 113 & 103 & 107 & 75 & 100 & 56 & 119 & 34 & 93 & 128 & 129 \\
\hline Co & 56 & 77 & 67 & 57 & 52 & 49 & 45 & 46 & 36 & 61 & 41 & 49 & 56 & 51 \\
\hline $\mathrm{Ni}$ & 190 & 461 & 347 & 167 & 155 & 118 & 69 & 87 & 34 & 358 & 21 & 194 & 265 & 177 \\
\hline $\mathrm{Sc}$ & 43 & 25 & 22 & 33 & 40 & 40 & 36 & 38 & 25 & 33 & 34 & 30 & 30 & 33 \\
\hline V & 331 & 185 & 176 & 229 & 283 & 264 & 271 & 238 & 260 & 299 & 349 & 230 & 222 & 245 \\
\hline $\mathrm{Cr}$ & 353 & 679 & 537 & 319 & 245 & 318 & 84 & 70 & 32 & 713 & 10 & 301 & 607 & 172 \\
\hline $\mathrm{Ga}$ & 19 & 16 & 17 & 20 & 20 & 20 & 21 & 22 & 23 & 20 & 25 & 18 & 20 & 19 \\
\hline
\end{tabular}

APPENDIX (continued).

\begin{tabular}{|c|c|c|c|c|c|c|c|c|c|c|c|c|c|c|}
\hline Site-unit & $917-81$ & $917-82$ & $917-83$ & $917-84$ & $917-85$ & $917-86$ & $917-87$ & $917-88$ & $917-89$ & $917-90$ & $917-91$ & $917-92$ & 918-01 & $918-05$ \\
\hline Series & Lower & Lower & Lower & Lower & Lower & Lower & Lower & Lower & Lower & Lower & Lower & Lower & Sill & SDRS \\
\hline Depth & 629.32 & 647.36 & 654.33 & 674.69 & 710.69 & 715.53 & 727.66 & 760.25 & 770.43 & 790.44 & 801.20 & 812.37 & 1176.24 & 1209.72 \\
\hline $\mathrm{SiO}_{2}$ & 48.74 & 48.66 & 47.17 & 47.87 & 46.48 & 47.18 & 46.42 & 43.52 & 46.80 & 46.90 & 47.31 & 47.89 & 48.68 & 49.35 \\
\hline $\mathrm{TiO}_{2}$ & 1.13 & 1.02 & 1.15 & 0.98 & 0.96 & 1.06 & 1.07 & 1.21 & 1.16 & 1.11 & 1.09 & 1.03 & 2.89 & 1.13 \\
\hline $\mathrm{Al}_{2} \mathrm{O}_{3}$ & 16.30 & 16.26 & 15.97 & 15.97 & 15.20 & 15.18 & 15.37 & 13.91 & 15.81 & 15.82 & 16.14 & 15.48 & 13.37 & 14.98 \\
\hline $\mathrm{Fe}_{2}^{2} \mathrm{O}_{3}$ & 4.06 & 3.03 & 3.97 & 4.58 & 6.01 & 4.63 & 3.46 & 5.26 & 3.53 & 3.95 & 4.96 & 4.50 & 3.54 & 5.52 \\
\hline $\mathrm{FeO}$ & 5.61 & 6.63 & 6.46 & 5.01 & 3.93 & 5.48 & 6.30 & 5.68 & 6.25 & 6.58 & 4.65 & 4.74 & 9.98 & 5.63 \\
\hline $\mathrm{MnO}$ & 0.15 & 0.16 & 0.18 & 0.17 & 0.18 & 0.19 & 0.17 & 0.20 & 0.18 & 0.19 & 0.20 & 0.20 & 0.22 & 0.30 \\
\hline $\mathrm{MgO}$ & 7.56 & 7.72 & 8.53 & 8.73 & 9.10 & 9.09 & 9.48 & 12.12 & 7.41 & 8.26 & 7.17 & 8.87 & 5.86 & 7.70 \\
\hline $\mathrm{CaO}$ & 9.96 & 9.98 & 9.78 & 10.39 & 10.75 & 10.88 & 9.49 & 8.51 & 10.71 & 10.42 & 12.15 & 10.95 & 10.65 & 10.26 \\
\hline $\mathrm{Na}_{2} \mathrm{O}$ & 2.78 & 2.55 & 2.45 & 2.39 & 2.11 & 2.16 & 2.32 & 1.66 & 2.34 & 2.28 & 2.39 & 2.17 & 2.63 & 2.40 \\
\hline $\mathrm{K}_{2} \mathrm{O}$ & 0.293 & 0.262 & 0.182 & 0.240 & 0.151 & 0.185 & 0.214 & 0.124 & 0.208 & 0.203 & 0.102 & 0.100 & 0.591 & 0.090 \\
\hline $\mathrm{P}_{2} \mathrm{O}_{5}$ & 0.137 & 0.122 & 0.151 & 0.115 & 0.100 & 0.113 & 0.157 & 0.094 & 0.144 & 0.140 & 0.135 & 0.123 & 0.360 & 0.059 \\
\hline $\mathrm{H}_{2} \mathrm{O}$ & 2.45 & 3.10 & 3.40 & 2.65 & 4.47 & 3.23 & 4.88 & 6.90 & 4.86 & 3.44 & 2.18 & 2.91 & 0.83 & 1.69 \\
\hline $\mathrm{CO}_{2}$ & 0.084 & 0.044 & 0.161 & 0.070 & 0.066 & 0.051 & 0.059 & 0.213 & 0.055 & 0.092 & 1.048 & 0.509 & 0.040 & 0.150 \\
\hline Sum & 99.25 & 99.56 & 99.54 & 99.13 & 99.48 & 99.41 & 99.39 & 99.40 & 99.41 & 99.39 & 99.51 & 99.45 & 99.65 & 99.25 \\
\hline $\mathrm{Rb}$ & 0.9 & 0.6 & 0.9 & 0.7 & 1.4 & 0.6 & 1.8 & 1.2 & 3.1 & 2.7 & 0.1 & 0.0 & 10.1 & 0.5 \\
\hline $\mathrm{Ba}$ & 254 & 217 & 283 & 198 & 221 & 204 & 341 & 88 & 659 & 978 & 172 & 138 & 181 & 13 \\
\hline $\mathrm{Pb}$ & 2 & 4 & 4 & 4 & 2 & 3 & 3 & 2 & 7 & 1 & 1 & 3 & 10 & 6 \\
\hline $\mathrm{Sr}$ & 335 & 328 & 399 & 303 & 463 & 363 & 388 & 263 & 454 & 411 & 388 & 326 & 242 & 94 \\
\hline $\mathrm{La}$ & 10 & 12 & 13 & 7 & 8 & 7 & 11 & 7 & 12 & 12 & 11 & 8 & 24 & 3 \\
\hline $\mathrm{Ce}$ & 24 & 20 & 25 & 18 & 13 & 19 & 22 & 11 & 23 & 22 & 23 & 18 & 55 & 10 \\
\hline $\mathrm{Nd}$ & 15 & 12 & 17 & 13 & 10 & 13 & 15 & 11 & 15 & 17 & 16 & 11 & 32 & 7 \\
\hline $\mathrm{Y}$ & 23 & 23 & 25 & 22 & 19 & 23 & 21 & 23 & 22 & 21 & 22 & 22 & 44 & 27 \\
\hline Th & 0 & 0 & 0 & 0 & 0 & 0 & 2 & 0 & 0 & 0 & 1 & 1 & 1 & 0 \\
\hline $\mathrm{Zr}$ & 81 & 68 & 76 & 63 & 47 & 53 & 68 & 73 & 66 & 62 & 69 & 57 & 197 & 53 \\
\hline $\mathrm{Nb}$ & 2.9 & 2.6 & 2.7 & 2.4 & 1.4 & 1.6 & 2.9 & 2.8 & 2.0 & 1.7 & 2.0 & 2.9 & 27.3 & 2.2 \\
\hline $\mathrm{Zn}$ & 94 & 89 & 88 & 82 & 79 & 75 & 78 & 73 & 82 & 77 & 80 & 80 & 116 & 97 \\
\hline $\mathrm{Cu}$ & 96 & 94 & 87 & 111 & 76 & 73 & 84 & 80 & 59 & 74 & 86 & 113 & 247 & 206 \\
\hline Co & 50 & 52 & 51 & 48 & 55 & 54 & 54 & 65 & 53 & 52 & 58 & 54 & 56 & 61 \\
\hline $\mathrm{Ni}$ & 170 & 169 & 162 & 188 & 200 & 178 & 243 & 373 & 128 & 118 & 155 & 290 & 63 & 76 \\
\hline $\mathrm{Sc}$ & 31 & 33 & 36 & 37 & 31 & 32 & 32 & 29 & 34 & 37 & 33 & 37 & 41 & 69 \\
\hline V & 257 & 248 & 282 & 239 & 204 & 211 & 230 & 217 & 233 & 246 & 253 & 224 & 407 & 402 \\
\hline $\mathrm{Cr}$ & 152 & 145 & 139 & 330 & 400 & 386 & 438 & 680 & 283 & 266 & 306 & 714 & 93 & 130 \\
\hline $\mathrm{Ga}$ & 20 & 20 & 19 & 20 & 18 & 17 & 20 & 18 & 18 & 20 & 19 & 18 & 23 & 18 \\
\hline
\end{tabular}


APPENDIX (continued).

\begin{tabular}{|c|c|c|c|c|c|c|c|c|c|c|c|c|c|c|}
\hline $\begin{array}{l}\text { Site-unit } \\
\text { Series } \\
\text { Depth }\end{array}$ & $\begin{array}{c}\text { 918-06 } \\
\text { SDRS } \\
1215.72\end{array}$ & $\begin{array}{c}918-07 \\
\text { SDRS } \\
1223.79\end{array}$ & $\begin{array}{c}918-08 \\
\text { SDRS } \\
1226.56\end{array}$ & $\begin{array}{c}918-09 \\
\text { SDRS } \\
1242.07\end{array}$ & $\begin{array}{c}918-10 \\
\text { SDRS } \\
1245.27\end{array}$ & $\begin{array}{c}918-11.1 \\
\text { SDRS } \\
1249.29\end{array}$ & $\begin{array}{c}918-11.2 \\
\text { SDRS } \\
1255.88\end{array}$ & $\begin{array}{c}918-12 \\
\text { SDRS } \\
1262.40\end{array}$ & $\begin{array}{c}918-13 \\
\text { SDRS } \\
1268.03\end{array}$ & $\begin{array}{c}918-14 \\
\text { SDRS } \\
1276.73\end{array}$ & $\begin{array}{c}918-15 \\
\text { SDRS } \\
1285.03\end{array}$ & $\begin{array}{c}918-16 \\
\text { SDRS } \\
1291.35\end{array}$ & $\begin{array}{c}918-17 \\
\text { SDRS } \\
1294.24\end{array}$ & $\begin{array}{c}918-18 \\
\text { SDRS } \\
1301.56\end{array}$ \\
\hline $\mathrm{SiO}_{2}$ & 47.33 & 49.41 & 49.70 & 49.39 & 49.79 & 47.28 & 50.38 & 49.91 & 49.99 & 50.24 & 49.63 & 49.77 & 49.43 & 50.01 \\
\hline $\mathrm{TiO}_{2}$ & 1.37 & 1.29 & 1.29 & 1.26 & 1.25 & 1.32 & 1.23 & 0.95 & 1.15 & 1.21 & 1.34 & 1.02 & 1.08 & 1.07 \\
\hline $\mathrm{Al}_{2} \mathrm{O}_{3}$ & 17.63 & 13.46 & 13.95 & 15.25 & 13.03 & 15.10 & 13.41 & 13.73 & 14.77 & 13.70 & 13.84 & 15.25 & 14.96 & 14.36 \\
\hline $\mathrm{Fe}_{2} \mathrm{O}_{3}$ & 7.59 & 6.00 & 5.56 & 6.11 & 4.79 & 11.01 & 4.44 & 3.85 & 5.55 & 4.85 & 5.19 & 6.25 & 6.43 & 10.53 \\
\hline $\mathrm{FeO}$ & 4.61 & 8.36 & 7.97 & 5.59 & 10.35 & 4.25 & 9.04 & 8.28 & 6.14 & 8.04 & 8.01 & 4.51 & 4.48 & 3.06 \\
\hline $\mathrm{MnO}$ & 0.27 & 0.29 & 0.28 & 0.25 & 0.34 & 0.09 & 0.33 & 0.23 & 0.18 & 0.19 & 0.30 & 0.22 & 0.25 & 0.22 \\
\hline $\mathrm{MgO}$ & 7.50 & 6.78 & 6.99 & 7.65 & 6.79 & 8.09 & 6.75 & 7.71 & 6.98 & 6.82 & 6.94 & 8.30 & 8.34 & 8.48 \\
\hline $\mathrm{CaO}$ & 6.29 & 8.98 & 9.67 & 8.89 & 8.53 & 5.82 & 9.97 & 11.29 & 10.02 & 10.94 & 10.12 & 9.18 & 9.00 & 3.52 \\
\hline $\mathrm{Na}_{2} \mathrm{O}$ & 2.70 & 2.45 & 2.47 & 2.61 & 1.78 & 2.82 & 2.40 & 2.10 & 2.44 & 2.33 & 2.34 & 2.43 & 2.38 & 2.23 \\
\hline $\mathrm{K}_{2} \mathrm{O}$ & 0.273 & 0.296 & 0.112 & 0.119 & 0.311 & 0.150 & 0.081 & 0.078 & 0.198 & 0.118 & 0.094 & 0.124 & 0.141 & 0.457 \\
\hline $\mathrm{P}_{2} \mathrm{O}_{5}$ & 0.054 & 0.069 & 0.082 & 0.074 & 0.067 & 0.078 & 0.075 & 0.050 & 0.058 & 0.080 & 0.089 & 0.049 & 0.041 & 0.054 \\
\hline $\mathrm{H}_{2} \mathrm{O}$ & 3.50 & 1.52 & 1.31 & 1.91 & 2.59 & 2.99 & 1.22 & 1.15 & 1.65 & 1.13 & 1.51 & 2.07 & 2.40 & 5.27 \\
\hline $\mathrm{CO}_{2}$ & 0.103 & 0.125 & 0.066 & 0.092 & 0.059 & 0.106 & 0.048 & 0.136 & 0.070 & 0.040 & 0.051 & 0.125 & 0.117 & 0.158 \\
\hline Sum & 99.20 & 99.03 & 99.44 & 99.16 & 99.67 & 99.08 & 99.36 & 99.42 & 99.17 & 99.69 & 99.45 & 99.29 & 99.06 & 99.40 \\
\hline $\mathrm{Rb}$ & 2.0 & 3.2 & 0.4 & 0.5 & 2.7 & 0.6 & 0.3 & 0.4 & 1.5 & 0.4 & 0.3 & 0.7 & 0.9 & 4.0 \\
\hline $\mathrm{Ba}$ & 18 & 13 & 20 & 16 & 16 & 18 & 15 & 16 & 21 & 28 & 18 & 12 & 11 & 10 \\
\hline $\mathrm{Pb}$ & 5 & 2 & 1 & 5 & 6 & 5 & 2 & 8 & 6 & 6 & 4 & 1 & 4 & 5 \\
\hline $\mathrm{Sr}$ & 103 & 78 & 94 & 100 & 63 & 99 & 85 & 77 & 92 & 90 & 89 & 90 & 90 & 77 \\
\hline $\mathrm{La}$ & 4 & 4 & 4 & 4 & 3 & 6 & 5 & 3 & 4 & 5 & 4 & 4 & 3 & 3 \\
\hline $\mathrm{Ce}$ & 7 & 8 & 12 & 9 & 9 & 11 & 9 & 6 & 9 & 10 & 12 & 6 & 9 & 8 \\
\hline $\mathrm{Nd}$ & 8 & 9 & 9 & 10 & 7 & 11 & 8 & 6 & 7 & 9 & 10 & 7 & 6 & 7 \\
\hline $\mathrm{Y}$ & 24 & 33 & 34 & 35 & 28 & 53 & 30 & 22 & 31 & 30 & 36 & 21 & 18 & 20 \\
\hline Th & 1 & 0 & 0 & 0 & 0 & 0 & 0 & 0 & 0 & 0 & 0 & 0 & 0 & 0 \\
\hline $\mathrm{Zr}$ & 62 & 63 & 62 & 59 & 61 & 61 & 60 & 42 & 55 & 58 & 65 & 47 & 50 & 50 \\
\hline $\mathrm{Nb}$ & 2.4 & 2.2 & 3.0 & 2.9 & 2.4 & 2.5 & 2.5 & 1.9 & 2.7 & 3.2 & 3.4 & 1.8 & 2.0 & 1.8 \\
\hline $\mathrm{Zn}$ & 118 & 122 & 114 & 112 & 131 & 104 & 115 & 98 & 113 & 100 & 108 & 100 & 95 & 140 \\
\hline $\mathrm{Cu}$ & 267 & 103 & 242 & 182 & 155 & 142 & 191 & 140 & 77 & 160 & 131 & 157 & 231 & 145 \\
\hline Co & 91 & 61 & 67 & 60 & 61 & 83 & 60 & 55 & 52 & 54 & 58 & 54 & 53 & 67 \\
\hline $\mathrm{Ni}$ & 111 & 54 & 63 & 77 & 57 & 77 & 55 & 78 & 77 & 69 & 69 & 79 & 83 & 99 \\
\hline $\mathrm{Sc}$ & 93 & 65 & 65 & 73 & 63 & 76 & 62 & 58 & 67 & 59 & 63 & 69 & 71 & 75 \\
\hline $\mathrm{V}$ & 498 & 417 & 410 & 435 & 386 & 421 & 425 & 331 & 394 & 350 & 393 & 375 & 400 & 384 \\
\hline $\mathrm{Cr}$ & 223 & 61 & 76 & 154 & 86 & 111 & 90 & 168 & 141 & 108 & 115 & 134 & 157 & 182 \\
\hline $\mathrm{Ga}$ & 22 & 21 & 22 & 20 & 19 & 21 & 20 & 17 & 21 & 21 & 18 & 20 & 20 & 19 \\
\hline
\end{tabular}

APPENDIX (continued).

Full ODP Sample Identification Codes for the Analyzed Samples

\begin{tabular}{|c|c|c|c|c|c|}
\hline Unit & Sample identification & Unit & Sample identification & Unit & Sample identification \\
\hline $915-3$ & 152-915A-24R-2, 68-72 cm, Piece 2B & $917-41$ & 152-917A-27R-2, 55-60 cm, Piece 6 & $917-82$ & 152-917A-83R-3, 61-65 cm, Piece 5 \\
\hline $917-1$ & 152-917A-6R-1, $84-88 \mathrm{~cm}$, Piece 8B & $917-43$ & 152-917A-30R-1, 74-79 cm, Piece 11 & $917-83$ & $152-917 \mathrm{~A}-84 \mathrm{R}-1,83-87 \mathrm{~cm}$, Piece $2 \mathrm{~A}$ \\
\hline $917-2$ & 152-917A-7R-2, 8-12 cm, Piece 1 & $917-44$ & 152-917A-30R-3, 52-56 cm, Piece 7 & $917-84$ & $152-917 \mathrm{~A}-86 \mathrm{R}-2,72-76 \mathrm{~cm}$, Piece 1B \\
\hline $917-6$ & 152-917A-8R-4, 5-8 cm, Piece 1 & $917-45$ & 152-917A-31R-1, $137-141 \mathrm{~cm}$, Piece 18A & $917-85$ & 152-917A-90R-1, 59-62 cm, Piece 2B \\
\hline $917-7$ & 152-917A-9R-1, 33-38 cm. Piece 4D & $917-47$ & $152-917 \mathrm{~A}-32 \mathrm{R}-4,10-15 \mathrm{~cm}$. Piece 3 & $917-86$ & $152-917 \mathrm{~A}-90 \mathrm{R}-5,45-48 \mathrm{~cm}$. Piece $1 \mathrm{~B}$ \\
\hline $917-9$ & 152-917A-10R-1, 80-84 cm, Piece $1 \mathrm{G}$ & $917-49$ & 152-917A-34R-2, 53-58 cm, Piece 4B & $917-87$ & $152-917 \mathrm{~A}-92 \mathrm{R}-4,27-31 \mathrm{~cm}$, Piece 2 \\
\hline $917-10$ & $152-917 \mathrm{~A}-10 \mathrm{R}-4,44-48 \mathrm{~cm}$. Piece $2 \mathrm{~A}$ & $917-50$ & $152-917 \mathrm{~A}-35 \mathrm{R}-2,13-18 \mathrm{~cm}$, Piece $1 \mathrm{~B}$ & $917-88$ & 152-917A-96R-1, 85-89 cm, Piece 8A \\
\hline $917-12$ & $152-917 \mathrm{~A}-11 \mathrm{R}-1,128-132 \mathrm{~cm}$, Piece $5 \mathrm{C}$ & $917-52$ & 152-917A-39R-3, 83-87 cm, Piece 6C & $917-89$ & $152-917 \mathrm{~A}-97 \mathrm{R}-2,18-21 \mathrm{~cm}$, Piece $1 \mathrm{~A}$ \\
\hline $917-13$ & $152-917 \mathrm{~A}-11 \mathrm{R}-4,22-26 \mathrm{~cm}$, Piece $1 \mathrm{~B}$ & $917-54$ & 152-917A-47R-3, 4-8 cm, Piece $1 \mathrm{~A}$ & $917-90$ & 152-917A-99R-2, 67-71 cm, Piece 1D \\
\hline $917-14$ & $152-917 \mathrm{~A}-12 \mathrm{R}-1,20-24 \mathrm{~cm}$. Piece 3 & $917-56$ & $152-917$ A-53R-1, $90-98 \mathrm{~cm}$. Piece 2 & $917-91$ & $152-917 \mathrm{~A}-100 \mathrm{R}-3,63-67 \mathrm{~cm}$. Piece $1 \mathrm{C}$ \\
\hline $917-16$ & $152-917 \mathrm{~A}-13 \mathrm{R}-2,38-42 \mathrm{~cm}$, Piece 1B & $917-57$ & 152-917A-53R-2, 20-28 cm, Piece 5 & $917-92$ & 152-917A-101R-4, 94-97 cm, Piece 6A \\
\hline $917-17$ & 152-917A-13R-5, 124-128 cm, Piece 11 & $917-58$ & $152-917 \mathrm{~A}-54 \mathrm{R}-5,43-48 \mathrm{~cm}$, Piece $1 \mathrm{~A}$ & $918-1$ & 152-918D-94R-1, 84-88 cm, Piece 4D \\
\hline $917-18$ & $152-917 \mathrm{~A}-14 \mathrm{R}-3,80-84 \mathrm{~cm}$, Piece 7 & $917-60$ & $152-917 \mathrm{~A}-55 \mathrm{R}-4,28-32 \mathrm{~cm}$, Piece $1 \mathrm{C}$ & $918-5$ & 152-918D-99R-4, 12-16 cm, Piece 1 \\
\hline $917-19$ & $152-917 \mathrm{~A}-15 \mathrm{R}-2,0-4 \mathrm{~cm}$, Piece $1 \mathrm{~A}$ & $917-61$ & 152-917A-57R-3, 73-76 cm, Piece $1 \mathrm{~A}$ & $918-6$ & $152-918 \mathrm{D}-100 \mathrm{R}-3,28-33 \mathrm{~cm}$, Piece $1 \mathrm{C}$ \\
\hline $917-21$ & 152-917A-16R-3, 66-70 cm, Piece 3A & $917-62$ & 152-917A-57R-7, 25-28 cm, Piece 1B & $918-7$ & 152-918D-101R-1, 9-12 cm, Piece 3 \\
\hline $917-24$ & 152-917A-17R-4, 64-68 cm, Piece 3A & $917-63$ & $152-917 \mathrm{~A}-58 \mathrm{R}-3,5-9 \mathrm{~cm}$, Piece $1 \mathrm{~A}$ & $918-8$ & 152-918D-101R-4, 87-92 cm, Piece 11 \\
\hline $917-25$ & 152-917A-18R-3, 89-93 cm, Piece 2 & $917-66$ & $152-917 \mathrm{~A}-62 \mathrm{R}-1,38-42 \mathrm{~cm}$, Piece 5A & $918-9$ & $152-918 \mathrm{D}-103 \mathrm{R}-2,31-35 \mathrm{~cm}$, Piece 1B \\
\hline $917-26$ & 152-917A-18R-4, 109-113 cm. Piece 7B & $917-68$ & 152-917A-64R-2, 39-43 cm. Piece 1B & $918-10$ & $152-918 \mathrm{D}-104 \mathrm{R}-2,80-85 \mathrm{~cm}$. Piece 11 \\
\hline $917-27$ & 152-917A-18R-6, 83-87 cm, Piece 5A & $917-70$ & 152-917A-67R-3, 122-126 cm, Piece 6B & $918-11.1$ & $152-918 \mathrm{D}-105 \mathrm{R}-2,24-28 \mathrm{~cm}$, Piece $4 \mathrm{~A}$ \\
\hline $917-30$ & 152-917A-19R-2, 46-51 cm, Piece 1B & $917-71$ & 152-917A-69R-2, 119-123 cm. Piece 4 & $918-11.2$ & 152-918D-106R-3, 86-91 cm, Piece 2B \\
\hline $917-31 \mathrm{~A}$ & 152-917A-19R-4, 55-59 cm, Piece 3 & $917-72$ & $152-917 \mathrm{~A}-71 \mathrm{R}-4,23-27 \mathrm{~cm}$, Piece 1C & $918-12$ & 152-918D-108R-1, 20-24 cm, Piece $2 \mathrm{~A}$ \\
\hline $917-31 \mathrm{~B}$ & $152-917 \mathrm{~A}-20 \mathrm{R}-1,42-45 \mathrm{~cm}$, Piece 4 & $917-73 \mathrm{~A}$ & 152-917A-72R-1, 57-61 cm, Piece 3D & $918-13$ & $152-918 \mathrm{D}-109 \mathrm{R}-1,113-117 \mathrm{~cm}$, Piece $2 \mathrm{~F}$ \\
\hline $917-32$ & 152-917A-20R-4, $128-131 \mathrm{~cm}$. Piece 11 & $917-75$ & 152-917A-76R-1, 72-82 cm. Piece 5 & $918-14$ & 152-918D-110R-4, 48-52 cm. Piece 6B \\
\hline $917-33$ & $152-917$ A-21R-3, 130-134 cm, Piece 5 & $917-76$ & 152-917A-78R-2, $125-129 \mathrm{~cm}$, Piece $4 \mathrm{~A}$ & $918-15$ & 152-918D-111R-3, 68-73 cm, Piece 8B \\
\hline $917-34$ & 152-917A-23R-1, 130-137 cm, Piece 17 & $917-78$ & 152-917A-79R-2, 71-75 cm, Piece 1D & $918-16$ & $152-918 \mathrm{D}-112 \mathrm{R}-1,45-50 \mathrm{~cm}$. Piece 9 \\
\hline $917-36$ & $152-917 \mathrm{~A}-25 \mathrm{R}-1,97-101 \mathrm{~cm}$. Piece 10 & $917-79$ & 152-917A-80R-3, $107-111 \mathrm{~cm}$. Piece 1D & $918-17$ & $152-918 \mathrm{D}-112 \mathrm{R}-3,47-51 \mathrm{~cm}$, Piece $5 \mathrm{~A}$ \\
\hline $917-38$ & 152-917A-26R-1, $130-135 \mathrm{~cm}$, Piece 17 & $917-81$ & $152-917 \mathrm{~A}-81 \mathrm{R}-1,54-58 \mathrm{~cm}$, Piece 6 & $918-18$ & $152-918 \mathrm{D}-113 \mathrm{R}-1,106-110 \mathrm{~cm}$, Piece $12 \mathrm{~B}$ \\
\hline $917-39$ & 152-917A-26R-2, 83-89 cm. Piece 13 & & & & \\
\hline
\end{tabular}

